\title{
Ostracods and rock facies across the Givetian/Frasnian boundary interval in the Sourd d'Ave section at Ave-et-Auffe (Dinant Synclinorium, Ardenne, Belgium)
}

\author{
Jean-Georges Casier, XaVier DeVleeschouWer, Sébastien Maillet, Estelle PetitclerC \& \\ ALAIN PRÉAT
}

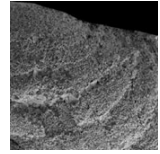

\begin{abstract}
Ostracods from the Sourd d'Ave section have been collected in the Moulin Boreux and Fort Hulobiet Members (Fromelennes Fm., Givet Group) and in the Pont d'Avignon Member (Nismes Fm., Frasnes Group). Ostracods collected in the Fromelennes Fm. by Milhau (1983a) and in the Nismes Fm. by Casier (1987a) have been also reviewed. Forty-four ostracod species are identified in the Fromelennes Fm. and 25 in the Nismes Fm. They belong exclusively to the Eifelian Mega-Assemblage, and several assemblages indicative of restricted and shallow marine, sometimes agitated, environments are recognized in the Fromelennes Fm. The great rarity of ostracods in the upper part of this formation provides evidence for less favourable lagoonal conditions probably related to increasing aridity at the end of the Givetian. In the Frasnes Group, assemblages are exclusively open marine and indicative of increasing water depth. The majority of ostracod species recognized in the Givet Group are missing in the base of the Frasnes Group as a consequence of the Frasnes Event. A systematic list of ostracods identified in the Fromelennes Fm. at Sourd d'Ave is published as an annex. Systematic sampling has been carried out in order to establish the sedimentological evolution of the environments and to detail the Givetian-Frasnian (G/F) transition. This allowed recognition of 13 microfacies types that replicate the standard sequence of Préat \& Mamet (1989) from open marine shallow subtidal to restricted supratidal near emersion. The Boreux Member and the Fort Hulobiet Member display restricted facies (Amphipora, spongiostromid and algal bafflestones and bindstones, loferites with desiccation lumps) with poorly fossiliferous beds interbedded with higher energy peloidal and sometimes oolitic grainstone facies. Laminite horizons, sometimes with small-sized lateral linked hemispheroid stromatolites are uncommon, and are associated with dolomicrites showing pseudomorphs of evaporite minerals. These evaporitic facies become common in the upper part of the Fort Hulobiet Member suggesting the palaeoclimate became more arid at the G/F transition. Metre-scale cyclicity is pervasive throughout the Givetian part of the section. The boundary between the Givet Group and the Frasnes Group is very distinctive in the field, and is characterized by a transition from restricted evaporative lagoonal facies to open marine interbedded marly shales and nodular limestones. The upper part of the Fort Hulobiet Member consists of interbedded biostromes (semi-restricted stromatoporoid boundstones) followed by Amphipora floatstones, then fossil-poor units and restricted supratidal laminites with well-developed fenestral fabrics. The Frasnian Pont d'Avignon Member contains a rich faunal assemblage (bryozoans brachiopods, molluscs, nautiloids, tentaculitids) suggesting an abrupt drowning from the marginal Givetian carbonate platform into a Frasnian distal ramp or deep basinal environment below or near storm wave base. - Key words: ostracods, palaeoecology, sedimentology, Givetian/Frasnian boundary, Fromelennes Formation, Nismes Formation, Dinant Synclinorium, Ardenne, Belgium.
\end{abstract}

Casier, J.-G., Devleeschouwer, X., Maillet, S., Petitclerc, E. \& PrÉAt, A. 2013. Ostracods and rock facies across the Givetian/Frasnian boundary interval in the Sourd d'Ave section at Ave-et-Auffe (Dinant Synclinorium, Belgium). Bulletin of Geosciences 88(2), 241-264 (10 figures, 2 tables, 1 annex). Czech Geological Survey, Prague. ISSN 1214-1119. Manuscript received February 3, 2012; accepted in revised form October 18, 2012; published online February 11, 2013; issued June 7, 2013.

Jean-Georges Casier (corresponding author), Department of Palaeontology, Royal Belgian Institute of Natural Sciences, Vautier street, 29, B-1000 Brussels, Belgium; casier@naturalsciences.be・Xavier Devleeschouwer, Belgian Geological Survey, Jenner street, 13, B-1000 Brussels, Belgium; xavier.devleeschouwer@naturalsciences.be - Sébastien Maillet, Laboratoire de Paléontologie stratigraphique, UMR8217, Faculté Libre des Sciences et Technologies de Lille, 41, rue du Port, F-59046 Lille Cedex, France; sebastien.maillet@icl-lille.fr • Estelle Petitclerc, Belgian Geological Survey, Jenner street, 13, B-1000 Brussels, Belgium; estelle.petitclerc@naturalsciences.be・Alain Préat, Département des Sciences de la Terre et de l'Environnement, Université libre de Bruxelles CP 160, Av. F.D. Roosevelt, 50,B-1050 Bruxelles,Belgique; apreat@ulb.ac.be 


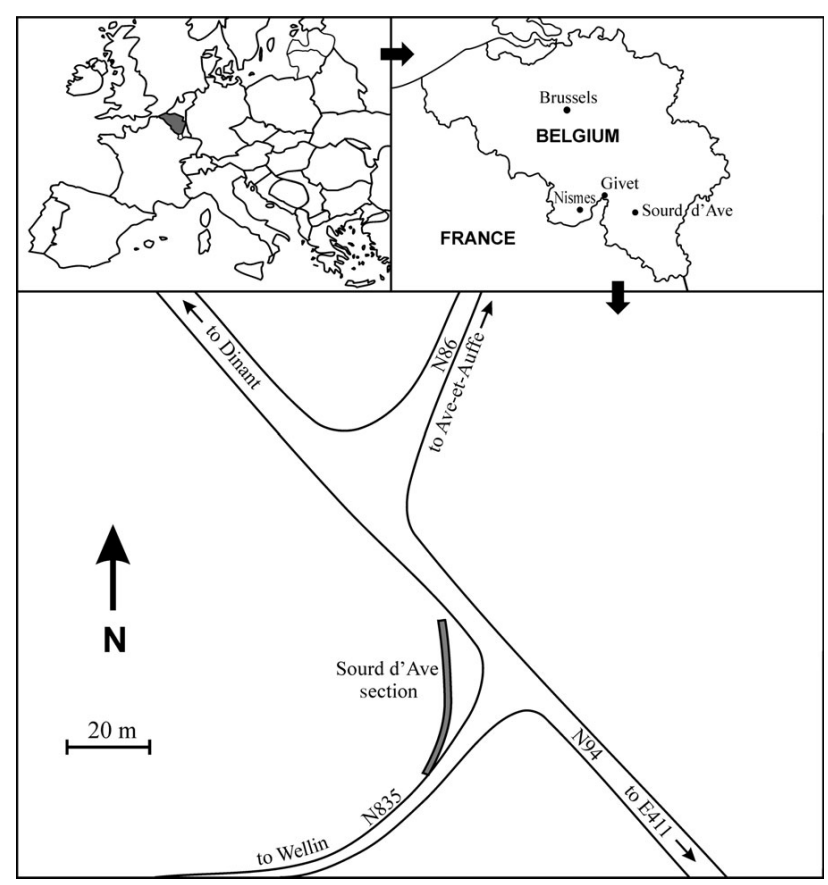

Figure 1. Locality map of the Sourd d'Ave section.

This paper forms part of a series on Devonian ostracods and their lithological context in the type region for the definition of the Givetian and Frasnian Stages (southern part of the Dinant Synclinorium). This new paper concerns the Givet Group/Frasnes Group transition exposed in the Sourd d'Ave section at Ave-et-Auffe (Dinant Synclinorium, Belgium). The transition is particularly well exposed in this classical reference section, and access is very easy.

The Sourd d'Ave section (from 5005.997` N; $05^{\circ} 07.873^{\prime} \mathrm{E}$ to $50^{\circ} 06.028^{\prime} \mathrm{N} ; 05^{\circ} 07.834^{\prime} \mathrm{E}$ ) is located at the intersection of the Dinant-Neufchâteau road (N48) and Han-sur-Lesse-Wellin road (N35) (Figs 1-3). The Givet Group is represented by the upper part of the Moulin Boreux Member (= Mbr) and the Fort Hulobiet Mbr, both belonging to the Fromelennes Formation (= Fm.). The Frasnes Group is represented by the Pont d'Avignon Mbr, by the Sourd d'Ave Mbr and by the base of the La Prée Mbr, all belonging to the Nismes Fm. (Fig. 4).

In the Sourd d'Ave section, the upper part of the Moulin Boreux Mbr is composed of $8 \mathrm{~m}$ of limestones comprising massive and branched stromatoporoids. The Fort Hulobiet Mbr is composed of $28 \mathrm{~m}$ of calcareous shales and argillaceous limestones. The Pont d'Avignon Mbr is represented by a $45 \mathrm{~cm}$-thick nodular argillaceous limestone. The Sourd d'Ave Mbr is 9.3 m-thick and made up of calcaro-argilaceous nodular shales with rare small argillaceous limestone beds. Finally the base of the La Prée Mbr consists of shales with rare calcaro-argillaceous nodules (Bultynck 1974, Casier 1987a, Bultynck et al. 1991, Boulvain et al. 1999).
The level of the Givetian/Frasnian boundary in the Dinant Synclinorium is still in debate. The ostracod study and the sedimentological analysis of the GSSP located at Puech de la Suque (Montagne Noire, France), where the boundary corresponds to the entry of an "early morph" of Ancyrodella rotundiloba (Klapper et al. 1987), suggests that the $\mathrm{G} / \mathrm{F}$ transition corresponds to the initiation of a sea-level rise (Casier \& Préat 2007). In fact, the Givetian/Frasnian boundary should be close to the Givet Group/Frasnes Group boundary in the Dinant Synclinorium, and certainly below the boundary designated in 1986 by the Subcommission on Devonian Stratigraphy, in the auxiliary stratotype at Nismes (Casier \& Préat 2009, 2010). That boundary is based on a "late morph" of Ancyrodella rotundiloba. In our paper, the Givetian/Frasnian boundary coincides arbitrarily with the Givet Group/ Frasnes Group boundary at the base of the bed where the first Ancyrodella have been recorded by Bultynck (1974), after a 15 m-thick episode without any conodonts.

Conodonts from the Sourd d'Ave section have been studied by Bultynck $(1974,1982)$ and by Narkiewicz \& Bultynck (2010). Several ostracod species occurring in the Fromelennes Fm. and Nismes Fm. exposed at Sourd d'Ave have been reported by Casier (1977, 1987a) and Milhau (1983a).

\section{Rock and facies analysis (A. Préat)}

Systematic sampling has been carried out in order to establish the evolution of palaeoenvironments and to detail the Givetian/Frasnian transition. This led to the fabrication of 260 thin sections (in Préat 1984) which allowed recognition of most of the 13 microfacies types that replicate the standard sequence of Préat \& Mamet (1989) from open marine shallow subtidal to restricted supratidal near emersion.

\section{Microfacies description}

\section{Open marine near or within the storm wave base}

Microfacies type 1 (or MF1). - Definition: shaly, micaceous silty microbioclastic, slightly to heavily burrowed mudstones-wackestones with thin levels of bioclastic wackestones-packstones. Bioclasts (a few hundreds microns in the packstone levels) consist mainly of echinoderms, brachiopods (some with spines), ostracods, molluscs, rare bryozoans, nautiloids and tentaculitids (Fig. 5A-E). Microbioclasts $(20-50 \mu \mathrm{m})$ are not easily recognizable and very often undeterminable. The matrix is often microsparitized with development of very fine 


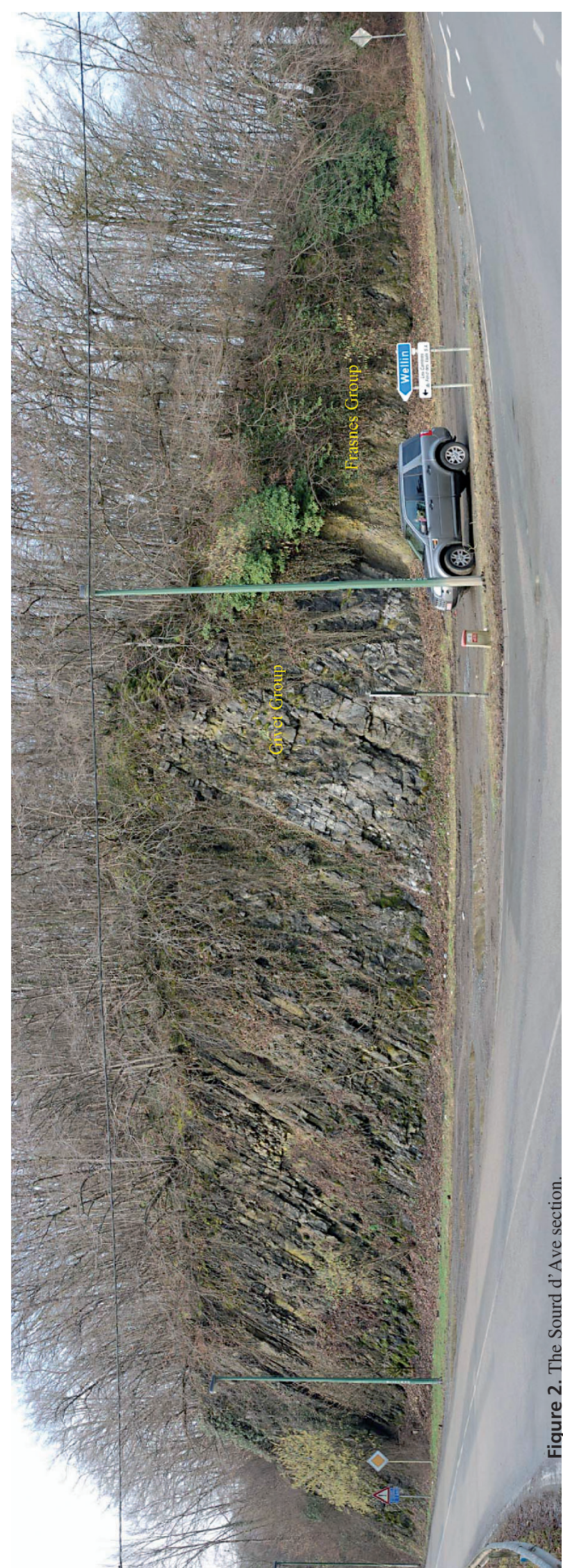

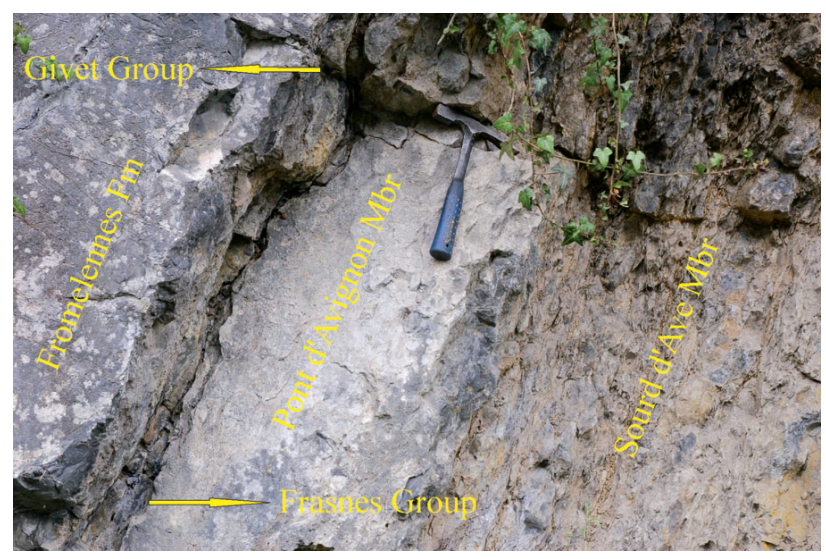

Figure 3. Detail of the Givet Group/Frasnes Group boundary in the Sourd d'Ave section.

grained (5-10 $\mu \mathrm{m}$, Fig. 5A) or coarse (30-50 $\mu \mathrm{m}$, Fig. 5C), sometimes "acicular" calcitic microspar (Fig. 5C). The coarsest microspar is associated with the most clay-rich matrix. The matrix is relatively homogeneous in the less microsparitized facies and contains fine-grained pyrite coating molluscs (Fig. 5A), abundant pyritospheres of the same type as those described in Casier et al. (2004) and fine-grained fragments of organic matter (around 50-100 $\mu \mathrm{m}$ ). Burrowing might be intensive and displaced microbioclasts (Fig. 5B). Silty material consists of subrounded quartz and is not abundant ( 1 to $5 \%$, Fig. 5D). Pressure solution processes are well expressed in the clayey facies and concentrated pyrite (Fig. 5E).

Microfacies type 2 (or MF2). - Definition: clayey, micaceous and silty burrowed microbioclastic wackestones with thin (up to $5 \mathrm{~mm}$-thick) laminar wackestones-packstones containing unmicritized bioclasts (echinoderms, brachiopods - some with spines-, molluscs, ostracods, rare trilobites and bryozoans, Fig. 5F-H). Microbioclasts are of the same type as in the previous facies and not abundant. Millimetric bioturbation features, sometimes with well-defined burrows, are well developed and can obliterate the primary laminations. Organisms are sorted by clast type, echinoderms are partly pyritized and brachiopods perforated with infillings of a silty muddy matrix. Very fine-grained silty material $(5-10 \mu \mathrm{m})$, consisting of subrounded quartz is slightly more abundant ( 1 up to $10 \%$ ) than previously, on the contrary micas are less abundant. The matrix is microsparitized as in the microfacies 1 . It is also dolomitized in the pressure solution seams with development of a finegrained $(10-50 \mu \mathrm{m})$ pyritized idiotopic dolomite. Pyrite and pyritospheres (Fig. 5G) are present as in microfacies 1.

Microfacies type 3 (or MF3). - Definition: laminar bioclastic wackestones and packstones. The latter contains exceptionally large subrounded microbreccias (up to $1.5 \mathrm{~cm}$ ) of previous MF1 or MF2 mudstones and wackestones. The 


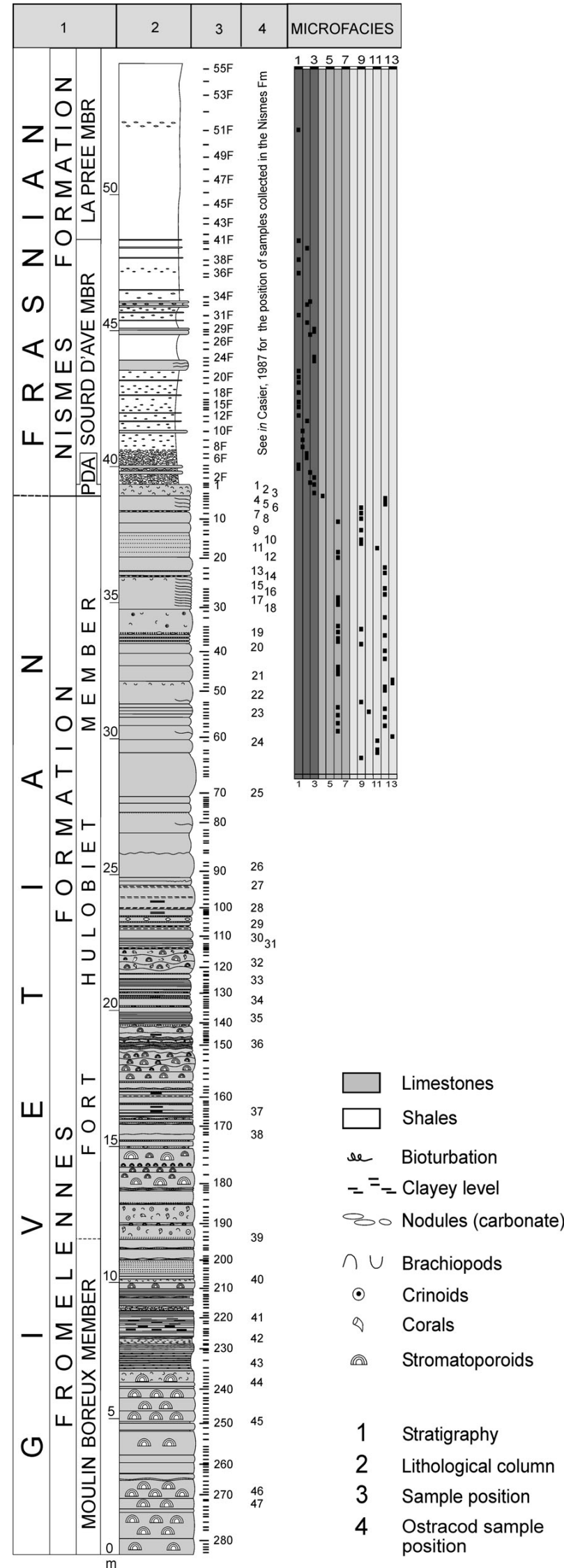

bioclasts of MF3 are more diverse and coarser (from $1 \mathrm{~mm}$ to $1 \mathrm{~cm}$, Fig. 6A, B) than in the previous facies. Bryozoans (fenestellids) are particularly well represented and sea urchin spines are regularly observed. The silty and clayey fraction is still present but more commonly absent. The bioclasts are unmicritized or slightly micritized and display high angle oblique stratifications or form elongate lenses. Bioturbation is still present and may destroy the laminations. The matrix is often recrystallized in a heterogeneous fine- to coarse-grained calcitic microspar. The echinoderm fragments can be very abundant and form medium-grained grainstones or encrinites up to $5 \mathrm{~mm}$ thick. They are associated with laminar fine- to medium-grained iron oolitic packstones (Fig. 6C, D).

\section{Open marine, peri-reefal environments near or within the fair-weather wave base}

Microfacies types 4 and 5 are not observed in the section.

Microfacies type 6 (or MF6). - Definition: stromatoporoid-coral floatstones (Fig. $6 \mathrm{~F}, \mathrm{H}$ ). The matrix is a bioclastic wackestone with crinoids, sea urchin spines (Fig. 6H) molluscs, brachiopods, ostracods (Fig. 6F), algae (mainly issinellids) and rare calcispheres. Stromatoporoids are mainly bulbous (dm-sized), sometimes laminar and encrusted by cyanobacteria (Bevocastria). This microfacies is often very easy to distinguish in the field, due to its rich faunal assemblage forming several metre-thick biostromes. Reciprocal encrustments between stromatoporoids and corals (mainly Tabulata, Thamnopora and Alveolites) are common. MF6 displays a variety of textures from floatstones through framestones, the former being the most common. The bioclasts can be aligned and parallel to each other delineating thin packstone levels. Disphyllids (Rugosa) are abundant towards the top of the section.

Microfacies type 7 (or MF7) - Definition: burrowed peloidal packstones and oolitic grainstones with erosive discontinuities. The facies is slightly dolomitized. Peloids are subrounded and well-sorted (50-200 $\mu \mathrm{m})$, a few lumps and small-sized bioclasts are associated. This microfacies is not well represented in the section.

\section{Restricted environments with salinity fluctuations}

Microfacies type 8 (or MF8). - Definition: gastropod and Amphipora packstone with various micritized bioclasts.

Figure 4. Sourd d'Ave section: lithological column, position of samples for the sedimentological analysis and for the ostracod study, microfacies (Lithologic survey: X. Devleeschouwer \& E. Petitclerc). 
The matrix is rich in various lumps and displays the appearance of a microbreccia. As for the previous microfacies, this microfacies is rare in the section.

Microfacies type 9 (or MF9). - Definition: burrowed peloidal algal (Issinella, Kamaena, Proninella and ?Labyrinthoconus - Mamet \& Préat 1987, Préat \& Mamet 1989) cyanobacterial (Bevocastria) wackestones with calcispheres, ostracods, Amphipora, pelecypods, gastropods, Bisphaera (Incertae sedis), a few umbellids, and sponge spicules (Fig. 7A). Amphipora may be so abundant that they form floatstones and bafflestones as the cyanobacteria forming bindstones. The Amphipora branches are well preserved and are often aligned parallel to bedding. The Amphipora and gastropods are often encrusted by Bevocastria leading to the formation of millimetric oncoids. Irregular lumps are associated with the Bevocastria encrustments. A fenestral fabric is present but not well represented and consists of irregular, vertical and sometimes laminoid fenestrae (Tebutt et al. 1965). Irregular fenestrae can be confused with various cavities resulting from the partial or complete dissolution of Amphipora. The facies is generally dominated by a few groups of these organisms and the matrix ranges from a mudstone to a wackestone. In this case the organisms are not diverse but they are abundant or very abundant. The facies is therefore characterized by impoverished or restricted microfaunas and microfloras. The matrix is a medium to dark grey colour micrite locally heavily bioturbated. It is sometimes argillaceous.

Microfacies type 10 (or MF10). - Definition: spongiostromid packstones and bindstones with abundant irregular peloids and lumps (Fig. 7B). A laminoid fenestral fabric is observed. Serpulids are regularly observed and can be very abundant.

Microfacies type 11 (or MF11). - Definition: loferite and peloidal stromatolitic bindstones with proto-oolites, calcispheres, subrounded and angular cryptalgal chips, subrounded lumps and thin irregular desiccation cracks (Fig. 7C-E). Cryptalgal chips sometimes become so numerous that the sediment becomes an intraformational microbreccia sometimes with thin erosional discontinuities. The chips, lumps and micritic matrix contain very small-sized bipyramidal quartz crystals similar to those described by Préat \& Mamet (1989) in the Givetian restricted facies of the Dinant Basin. The fauna is very poor, mainly comprised of ostracods and Amphipora. Bisphaera (Incertae sedis) and Palaeomicrocodium (Mamet \& Préat 1985) are also observed. The matrix contains abundant laminoid fenestrae and sponge spicules. The matrix is occasionally slightly recrystallized and displays a very fine-grained calcitic or dolomitic (idiotopic crystals, 20-50 $\mu \mathrm{m}$ ) microspar and coarser clear blocky and granular calcite.
Microfacies type 12 (or MF12). - Definition: laminar peloidal packstones and very fine-grained grainstones with disrupted flat laminations similar to those on the modern carbonate tidal flats of the Andros Island (Hardie \& Ginsburg 1977). The sediment of the Andros tidal flat belt is mainly a pelleted carbonate mud showing varying degrees of induration. The layering is produced by the alternation of physical sedimentation with the growth of algal mats (mainly Scytonema). The millimetric layering of our microfacies 12 is formed by the alternation of thin levels (up to $5 \mathrm{~mm}$ thick) of muddy sediments and thicker layers of wellsorted peloidal (from cyanobacterial mats?) microbioclastic (ostracods, molluscs, issinellids, kamaenids, proninellids) packstones and grainstones. Some calcispheres and rare umbellids are also observed. Desiccation and sheet cracks filled with clays are common as tubular and laminoid fenestrae, some of which have geopetal infillings (dismicrite, Fig. 7E). As for the previous facies erosional discontinuities are observed as microsparitization. Large hexagonal quartz crystals with anhydrite inclusions are present in the matrix.

Microfacies type 13 (or MF13). - Definition: very finegrained peloidal dolopackstones and dolomudstones with rare pelecypods, Amphipora, issinellids, kamaenids and calcispheres. The dolomitic crystals are idiotopic and range from 20 to $50 \mu \mathrm{m}$ in size (Fig. 7H). Filamentous pyrite (Mamet \& Préat 2005a) is frequently observed in the matrix. Calcite pseudomorphs of rosette-like and acicular crystals are occasionally observed (Fig. 7G) and are of the same types as those reported in the Upper Givetian by Préat \& Mamet (1989).

\section{Sedimentological and palaeoecological evolutions (Table 1)}

\section{Sedimentary model}

Microfacies types 1 to 3 display mudstone and wackestone textures with well preserved open-marine faunas deposited near or below the storm wave base. They contain thin coquina packstone levels constituted by reworked, broken-up faunas deposited between the storm wave base and fair-weather wave base (Aigner 1985, Einsele \& Ricken 1991). The laminar levels are rare and thin (MF1), of intermediate thicknesses (MF2) and finally thick and abundant (MF3), and they contain similar bioclasts. These microfacies are episodically present in the Fromelennes Fm. and represent the only interbedded carbonate facies in the shaly nodular Nismes Fm. In the field they display highly fossiliferous wackestones and packstones (brachiopods, crinoids with some disphyllids, various solitary corals and rare stromatoporoids). The presence of a fully open marine 
Table 1. Summary of microfacies and interpreted environments.

\begin{tabular}{|c|c|c|c|c|c|}
\hline Microfacies & Thickness & Sedimentary structures & Bioclasts & Remarks & Environment \\
\hline MF1 shales, shaly mdst/wkst & $\mathrm{cm}-\mathrm{dm}$ & $\begin{array}{l}\text { homogeneous, burrows, } \\
\text { distal tempestites }\end{array}$ & $\begin{array}{l}\text { microbioclasts: echinoderms, } \\
\text { brachiopods, ostracods, } \\
\text { bryozoans nautiloids, } \\
\text { tentaculitids }\end{array}$ & $\begin{array}{l}\text { acicular calcitic } \\
\text { microspar }\end{array}$ & $\begin{array}{l}\text { open marine near } \\
\text { SWB }\end{array}$ \\
\hline MF2 shales, shaly mdst/wkst & $\mathrm{cm}-\mathrm{dm}$ & intermediate tempestites & same as MF1 & & open marine in SWB \\
\hline MF3 laminar wkst/pkst & $\mathrm{dm}$ & proximal tempestites & $\begin{array}{l}\text { more diversified, more abundant } \\
\text { coarser }\end{array}$ & $\begin{array}{l}\text { rounded } \\
\text { microbreccias and } \\
\text { iron oolites }\end{array}$ & $\begin{array}{l}\text { open marine SWB } \\
\text { near FWWB }\end{array}$ \\
\hline \multicolumn{6}{|l|}{ MF4 \& MF5 * } \\
\hline MF6 floatstone \& (framestone) & $\mathrm{dm}-\mathrm{m}$ & & $\begin{array}{l}\text { stromatopores, corals and } \\
\text { diversified \& abundant bioclasts }\end{array}$ & algae & peri-reefal photic zone \\
\hline MF7 peloidal pkst/oolitic gst & $\mathrm{cm}-(\mathrm{dm})$ & internal bedding & rare & & restricted channels \\
\hline MF8 gastropod-Amphipora pkst & $\mathrm{cm}-(\mathrm{dm})$ & internal bedding & rare (micritized bioclasts) & & restricted shoals \\
\hline $\begin{array}{l}\text { MF9 cyanobacterial/algal wkst/ } \\
\text { bafflestone }\end{array}$ & $\mathrm{dm}$ & abundant fenestrae & $\begin{array}{l}\text { calcispheres, Amphipora, } \\
\text { mollusks, Umbellids... }\end{array}$ & $\begin{array}{l}\text { endemism of } \\
\text { faunas/floras }\end{array}$ & $\begin{array}{l}\text { restricted with salinity } \\
\text { variations }\end{array}$ \\
\hline MF10 spongiostromide bindstone & $\mathrm{cm}-\mathrm{dm}$ & irregular laminae & serpulids & $\begin{array}{l}\text { calcitic or dolomitic } \\
\text { matrix }\end{array}$ & idem \\
\hline $\begin{array}{l}\text { MF11 loferite-microstromatolitic } \\
\text { bindstone }\end{array}$ & $\mathrm{cm}-\mathrm{dm}$ & $\begin{array}{l}\text { desiccation cracks } \\
\text { intraformational breccias }\end{array}$ & 'cryptalgal’ chips, calcispheres & & idem \\
\hline MF12 laminar peloidal pkst & $\mathrm{cm}-\mathrm{dm}$ & $\begin{array}{l}\text { disrupted flat laminae } \\
\text { millimetre layering }\end{array}$ & algae, mollusks, ostracods & $\begin{array}{l}\text { quartz crystals with } \\
\text { anhydrite }\end{array}$ & supratidal plain \\
\hline MF13 dolopkst/dolomdst & $\mathrm{cm}-\mathrm{dm}$ & & idem with Amphipora & pseudomorphs & evaporitic \\
\hline
\end{tabular}

* not observed (see text)

mdst $=$ mudstone, wkst $=$ wackestone, pkst $=$ packstone, gst $=$ grainstone, $\mathrm{SB}=$ storm wave base, $\mathrm{FWWB}=$ fair weather wave base

assemblage is suggestive of a general distal open marine depositional environment below normal wave base. Storms occasionally impinged into this environment, therefore an environment at (MF2 and MF3), or just below (MF1) storm wave base is suggested. The significant facies change at the Givetian/Frasnian boundary, that records similar microfacies to those described by Préat \& Kasimi (1995) suggests that carbonate and shale deposition was initiated in a homoclinal ramp where a slight slope (absence of turbidites) existed with no true barrier or topographic differentiation. Casier \& Préat (2009) have shown in the Nismes G/F parastratotype, close to Frasnes (southern border of Dinant Basin) that the Givetian carbonate platform was drowned and dismantled prior its definitive drowning. This major sedimentary change also reported in the Sourd d'Ave section might be attributed to a sedimentary evolution of a "Givetian" carbonate platform to a Lower Frasnian mixed ramp system.

Microfacies 6 and 7 are observed only in the Fromelennes Fm. Microfacies 6 consists of stromatoporoid-coral floatstones and is easy to identify in the field due to the presence of recognizable large macrofaunas. Strata are generally well bedded, with beds between a few $\mathrm{dm}$ to one meter in thickness, but commonly being about 40 to $50 \mathrm{~cm}$ thick. Stromatoporoids are variable in size (around $10 \mathrm{~cm}$ in diameter) and do not construct recognizable bioherms. They appear as well- to poorly-bedded biostromes with a bioclastic matrix variably composed of bulbous, globular

Figure 5. Thin sections are deposited in the Department of Earth Sciences and Environment of the University of Brussels (ulb/sed ....). SF- and SG- $=$ sample number (see Fig. 4 for the stratigraphic position). Open marine environment. - A - bioclastic (molluscs, ostracods) wackestone with a slightly recrystallized fine-grained calcitic microspar. Blackish zones covering bioclasts are small-sized pyrite. Open-marine environment near the storm wave base-level. MF1, ulb/sed 9036-11, sample SG-4, Fromelennes Fm. • B, C - burrowed bioclastic (echinoderms, molluscs, ostracods). Blackish zones are spheroidal pyrite dispersed in the micrite (B). Irregular zones with very coarse grained calcitic microspar and associated pyrite around brachiopods are present in C. Open-marine environment near the storm wave base-level. MF1, ulb/sed 9041-11 (B) and 9044-11 (C), sample SF-10, Nismes Fm. • D - Bioclastic (brachiopod) burrowed silty wackestone. Open-marine environment near the storm wave base-level. MF1, ulb/sed 9053-11, sample SF-4, Nismes Fm. -E - bioclastic mudstone with brachiopod shells and spines. Irregular pyritic and calcitic pressure solution seams and dendritic pyrite microtufts developed later in the matrix. Open-marine environment near the storm wave base-level. MF1, ulb/sed 9059-11, sample SF-15, Nismes Fm. • F, G - bioclastic (bryozoans and brachiopods in F and only brachiopods in G) silty packstone forming a thin layer in a fine-grained wackestone. The zoecia of the bryozoans are filled with very small-sized pyrite spheres. Open-marine environment in the storm wave base-level (distal tempestite). MF2, ulb/sed 9047-11 (F) and 9049-11 (G), sample SF-7, Nismes Fm. • H - bioclastic (brachiopods, echinoderms, ostracods) packstone forming a thin burrowed layer in a fine-grained wackestone. Open-marine environment near the storm wave base-level (distal tempestite). MF2, ulb/sed 9030-11, sample SF-3, Nismes Fm. 

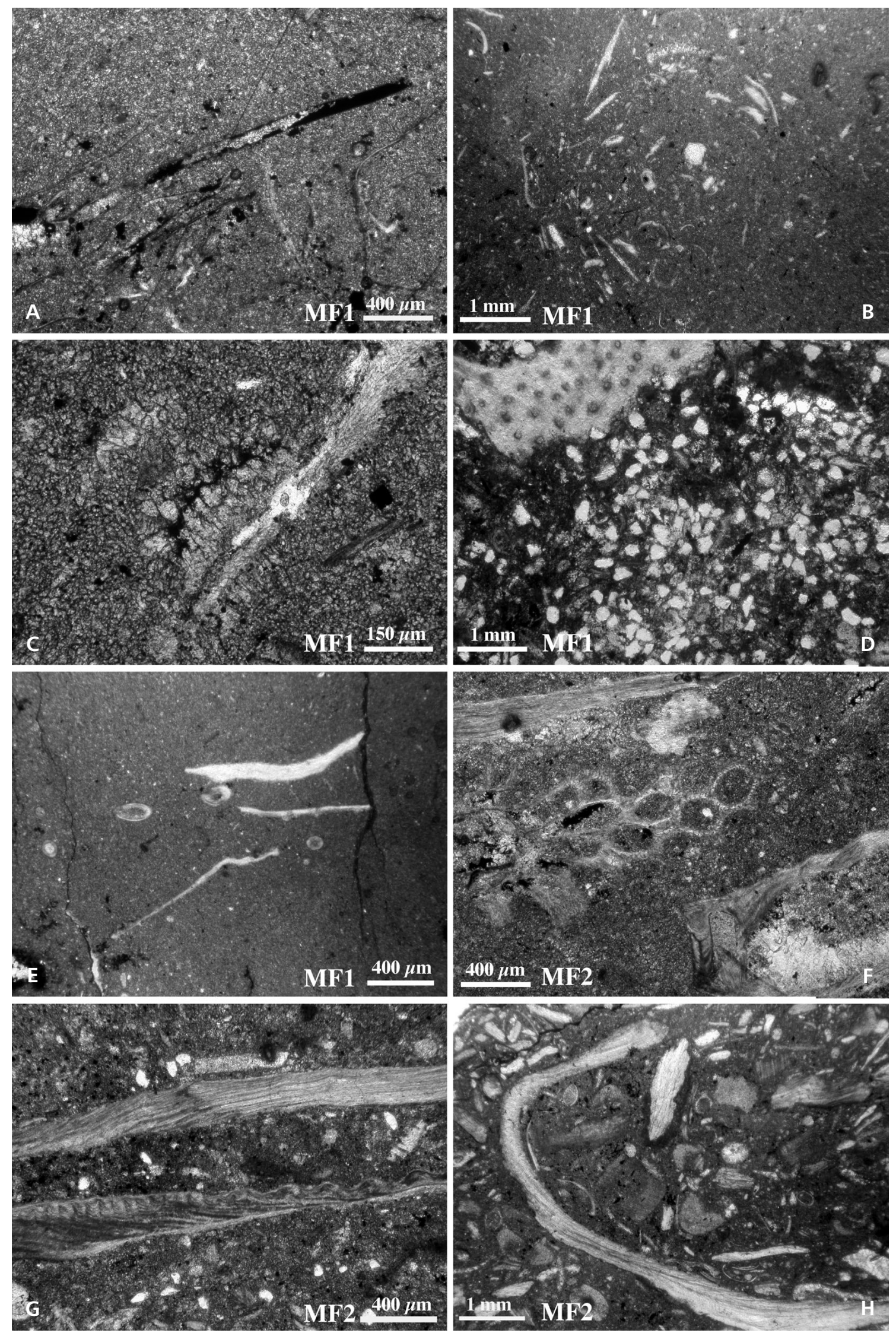
and rare laminar stromatoporoids, corals (Tabulata thamnoporoids, alveolitids - and solitary Rugosa), crinoids, and brachiopods. Bioconstructors are rarely preserved in their life position (framestone), but they are not very broken-up, pointing to only minor transportation in moderate energy environments except during storm events, which episodically dislodged the macrofaunas. No large scale cross bedding has been identified suggesting that higher-energy conditions were not encountered in this shallow (presence of algae in thin sections) marine environment. Oolitic packstones and grainstones of microfacies 7 are not well represented and suggest moderate to high-energy conditions with constant wave action in subtidalintertidal channels. Modern-day ooids form in shoals, tidal deltas, lakes and foreshore zones with water as deep as $15 \mathrm{~m}$ but usually less than $5 \mathrm{~m}$ (Westphal et al. 2010). Microfacies 7 formed thin oolitic accumulations (less than one $\mathrm{dm}$ ) and probably represent small temporary sand banks with the moderate-energy slightly restricted subtidal zone as also suggested by the abundance of peloids (Préat \& Mamet 1989, Flügel 2004, Tucker \& Garland 2010). The absence of microfacies 4 and 5 indicates that no true or important reefal barrier or biohermal lenses (Mamet \& Préat 2005b, Préat et al. 2007) were developed in the sedimentation area.

Microfacies 8 to 13 are only observed in the Fromelennes Fm. (as for MF6 and 7) and are extremely common in the studied section. The previous open marine fauna (of MF1-3) is absent or very rare and deposition was at very shallow depths or near emersion. Most organisms of the open marine facies are replaced by endemic faunas (ostracods, Amphipora, molluscs, sponges), floras (algae, calcispheres) and microbial mats (cyanobacteria, "spongiostromids", "stromatolites"). The facies are well-bedded, and the bedding is mostly planar and ranges from a few $\mathrm{cm}$ to a few $\mathrm{dm}$ in thickness, commonly being $5 \mathrm{~cm}$ to $7 \mathrm{~cm}$ thick. This set of microfacies is characterized by macrofossil-poor muddy sediments, or by monospecific (micro)fossil assemblages. Microfacies 9 and 11 are also well represented, but the others are not common. They include Amphipora floatstones (MF8), algal wackestones and bindstones (MF9), spongiostromid packstones and bindstones (MF10), stromatolitic bindstones (MF11), peloidal laminar packstones (MF12) and dolomudstones (MF13). Amphipora is extremely common in the Sourd
d'Ave section and is considered to indicate warm temperatures in a restricted quiet environment (Flügel 2004). The presence of the dense accumulation (bafflestone) of this organism and the sometimes uniform orientation of their well preserved delicate branches suggest that these accumulations were deposited close to their living site. The optimum depths of the amphiporids are less than $10 \mathrm{~m}$, sometimes around $1 \mathrm{~m}$ (Racki 1993). They were deposited in backreef environments in calm water, shallow lagoon characterized by abundant calcispheres, algae and cyanobacteria present in microfacies 9. These facies assemblages (microfacies 9-12) are partly associated with intertidal to supratidal zones as suggested by the occasional fenestral laminoid fabric. These fenestrae are thought to have formed through desiccation processes in subaerial zones (Tebbutt et al. 1965) as a result of early diagenetic alteration of cyanobacterial mats. This is equivalent to the MF9a defined by Préat \& Mamet (1989) in the broad Givetian shelf lagoon of the southern Ardennes. High intertidal and supratidal facies are characterized by the development of spongiostromids and lateral linked hemispheroid (= LLH) stromatolites in microfacies 10 and 11. Intraformational breccias and mudcracks characterize these facies. Mudchips and subangular lumps resulted from the probable destruction of mud polygons. The faunas and floras (algae) are rare and the development of a laminoid fenestral fabric highlights the stressful conditions of the environment. Supratidal laminites (MF12) and very fine-grained dolomudstones (MF13) capping this standard sequence record a shallow, calm, highly restricted environment that was subject to evaporitic, subaerial conditions (MF13). Episodic hurricanes or particular strong tidal currents tides affected the cyanobacterial mats, which colonized the supratidal surface or littoral plain where cyanobacteria either agglutinated or baffled the sediment. The repetition of this process leads to the formation of these supratidal laminites (Boulvain \& Préat 1987).

\section{Palaeoecological evolution at the G/F boundary}

The Moulin Boreux Mbr and Fort Hulobiet Mbr display restricted facies (Amphipora, spongiostromid and algal bafflestones and bindstones, loferites with desiccation lumps or crytpalgal chips) and poorly fossiliferous beds interbedded

Figure 6. Open marine and fore-shoal environments. - A, B - partly burrowed bioclastic (brachiopods, echinoderms) packstone with a slightly recrystallized fine-grained calcitic microspar. Blackish zones covering some bioclasts are small-sized pyrite. Pyritic pressure solution seams are abundant between the bioclasts. Open marine fore-shoal near the fair-weather wave base-level. MF3, ulb/sed 9025-11 (A) and 9027-11 (B), sample SG-4, Fromelennes Fm. • C, D, E - laminar partly pyritized oolitic and bioclastic (altered echinoderms) packstone. The matrix is a medium-grained calcite microsparite. Open marine fore-shoal near the fair-weather wave base-level. MF3, ulb/sed 9066-11 (C), $9068-11$ (D) and 9069-11 (E), sample SF-23, Nismes Fm. $\bullet$ F - stromatoporoid floatstone with ostracod and molluscan bioclasts in a wackestone matrix. Slightly agitated peri-reefal environment near a bioconstruction. MF6, ulb/sed 8980-sample SG-52, Fromelennes Fm. • G, H - stromatoporoid floatstone with ostracod, coral, echinodermal (sea urchin spine, $\mathrm{H}$ ) and molluscan bioclasts in a packstone matrix. Agitated peri-reefal environment near a bioconstruction. MF6, ulb/sed 9009-11 (G) and 9010-11 (H), sample SG-35, Fromelennes Fm. 

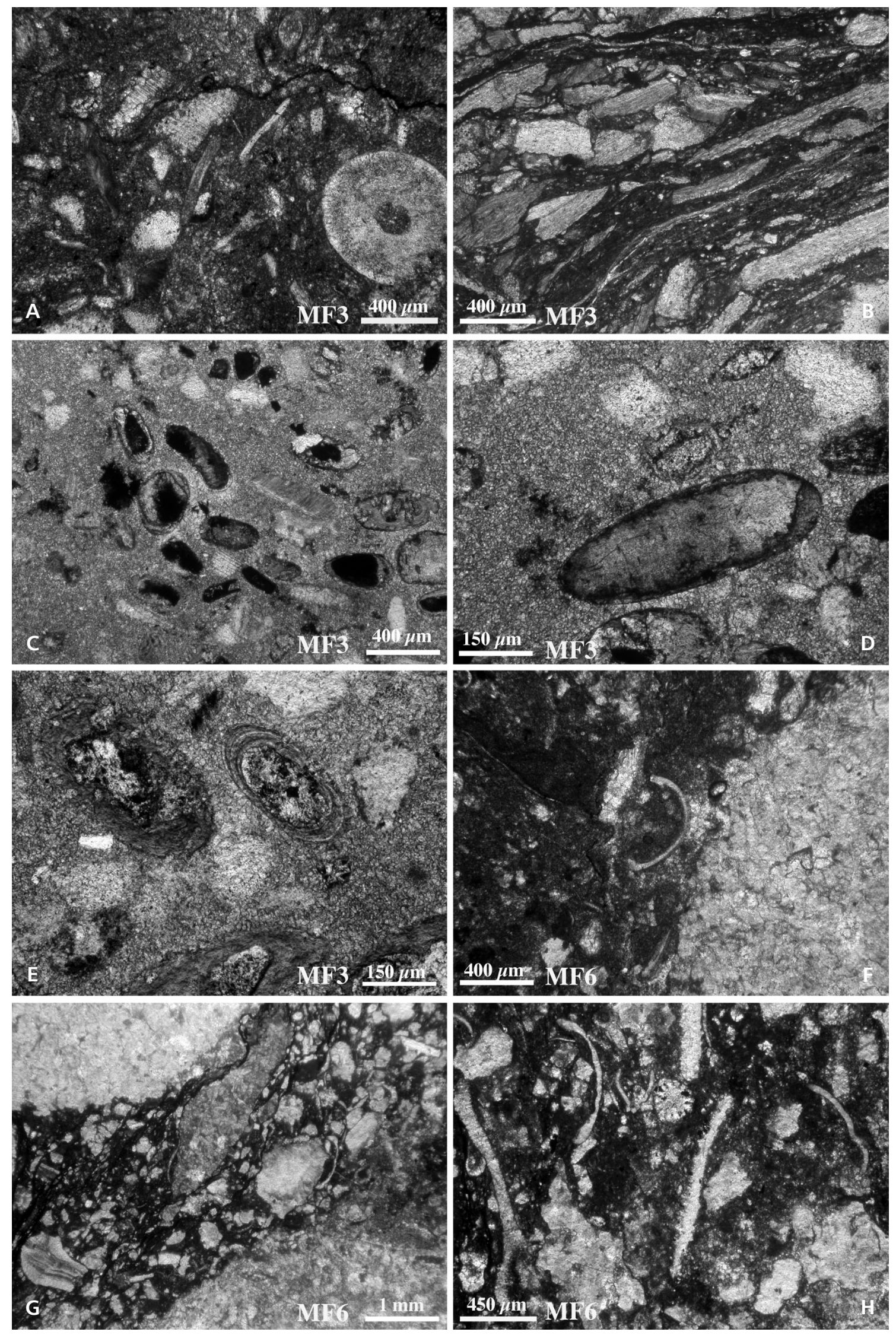
with higher energy peloidal and sometimes oolitic grainstone facies. Laminite horizons, sometimes with small-sized LLH-stromatolites are uncommon, and they are associated with dolomicrites containing pseudomorphs of evaporite minerals. These evaporitic facies become common in the upper part of the Fort Hulobiet Mbr suggesting the palaeoclimate became more arid during the Givetian/Frasnian transition. The boundary between the Givetian and the Frasnian, which is very distinctive in the field, is characterized by a transition from semi-restricted peri-reefal environments (MF6-7) and restricted evaporative lagoonal facies (MF8-13) to open marine interbedded marly shales and nodular limestones (MF1-3). This evolution could reflect the transition of a restricted carbonate platform (Préat \& Mamet 1989) to a mixed siliciclastic ramp system similar to the one observed in the Eifelian of Belgium and France (Préat \& Kasimi 1995).

Metre-scale cyclicity is very pervasive throughout the Givetian part of the section. Cyclicity was determined by assessing the vertical stacking of facies, the base of a cycle being identified by the initial backstepping of less restricted facies-type over a restricted facies-type. Cycles have open or semi-restricted subtidal bases with stromatoporoids, crinoids, corals and restricted supratidal tops with common "algal chips". They record a decrease in circulation, a decrease in diversity of organisms, which are endemic (cyanobacteria, stromatolites, ostracods, gastropods, umbellids), and an increase in salinity upwards through the cycles. Horizons rich in ostracods are commonly seen representing the impingement of storms in the low energy restricted lagoons. Oncoids are locally abundant in specific horizons. The upper part of the Fort Hulobiet Mbr consists of interbedded biostromes (semi-restricted stromatoporoid boundstones) overlain by Amphipora floatstones, then fossil-poor units and restricted supratidal laminites with well-developed fenestral fabrics. The Frasnian Nismes Fm. shows a rich faunal assemblage (bryozoans, brachiopods, molluscs, nautiloids, tentaculitids) suggesting a deepening of the Frasnian from the marginal Givetian carbonate platform to a deeper distal ramp or basinal environment below or near the storm wave base.

\section{Ostracods (J.-G. Casier \& S. Maillet)}

\section{Previous studies}

In 1977, Casier discussed ostracods from the lower part of the Nismes Fm. at Sourd d'Ave, and later (1987a), he published a paper on ostracods from the Frasnes Group exposed in this section, and in another lateral, but slightly higher section. Those two sections were separated by a hiatus of $20 \mathrm{~m}$. The list of ostracods recognized by Casier $(1977,1987$ a) is also reported in Bultynck et al. (1988).

In a paper on the biostratigraphic and palaeoecological values of ostracods in the type-region for the Upper Givetian, Milhau (1983a) identified ostracods from the Sourd d'Ave section. His study, based on 5 samples collected in the Fromelennes Fm. recognized the following 30 ostracod species, of which 27 are in open nomenclature: Bairdiocypris cf. Bairdia (B.) sp. nov. Groos, 1969, Quasillitacea gen. indet. sp. A, Healdianella sp. 1, Bythocypris? sp. G1' Magne, 1964, Birdsallella? sp. indet., Microcheilinella $\mathrm{cf}$. clava (Kegel, 1932), Cryptophyllus sp. 3 Magne, 1964, Acratia sp. 1, Bairdiocypris cf. rauffi Krömmelbein, 1952, Cavellina sp. 1, Cytherellina cf. sp. 1, Cytherellina cf. perlonga (Kummerow, 1953), Cytherellina sp. 2, Eridoconcha? sp. 1, Knoxiella sp. 1, Polyzygia neodevonica (Matern, 1929), Uchtovia? sp. 1, Sulcella (P.) abundans (Pokorný, 1950), Samarella aff. crassa Polenova, 1952, Cavellina cf. sp. II Groos, 1969, Bairdia (R.) sp. 1, Evlanella sp. 1, Evlanella cf. sulcellina? Becker, 1964, Macrocypris? sp. G Magne, 1964, Sulcella? sp. 3, Sulcella (S.) speculaea Becker, 1965, Evlanella sp. 2, Nodella sp. 1, Quasillitacea gen. indet. sp. B, and probably Silenites? sp. G Magne, 1964.

In the same section, Milhau (Ibid.) mentioned the presence of Paraparchitidae gen. and sp. indet., Jenningsina sp. indet. and Polyzygia beckmanni Krömmelbein, 1954, in the Pont d'Avignon Mbr, and of Jenningsina sp. indet., Polyzygia beckmanni Krömmelbein, 1954, Plagionephrodes sp. indet., Ponderodictya sp. C3 Magne, 1964 and Punctomosea weyanti Becker, 1971, in the base of the Sourd d'Ave Mbr.

Figure 7. Restricted lagoonal environments. • A - spiculitic (sponge) wackestone. The calcitic spicules are partly dissolved. Restricted lagoon. MF9, ulb/sed 9018-11, sample SG-23, Fromelennes Fm. • B - peloidal packstone with a very fine-grained microsparitized calcitic matrix. A subrounded micritic microbreccia containing a sponge spicule is present. Intertidal channel in a restricted environment. MF10, ulb/sed 8971-11, sample SG-54, Fromelennes Fm. $\bullet$ C - peloidal laminar packstone with curved mudcrack and poorly developed fenestral fabric. Supratidal levee associated with an intertidal channel bordering a restricted environment. MF11, ulb/sed 8964-11, sample SG-56, Fromelennes Fm. • D - peloidal laminar loferitic packstone with well sorted subrounded lumps and coated grains. Supratidal-intertidal levee-channel in a restricted environment. MF11, ulb/sed 8990-11, sample SG-49, Fromelennes Fm. • E - calcispherid peloidal microsparitized wackestone with small-sized unrecognizable bioclasts. Restricted lagoonal environment. MF11, ulb/sed 8950-11, sample SF62, Fromelennes Fm. • F - "dismicrite" with irregular geopetal lofertic cavities in a homogeneous mudstone. Restricted lagoonal environment. MF12, ulb/sed 9015-11, sample SG-23, Fromelennes Fm. • G - peloidal dolopackstone with dolomite pseudomorph after a former sulphate mineral? MF13, ulb/sed 8954-11, sample SG-60, Fromelennes Fm. • H - dolomudstone with idiotopic 20-50 $\mu$ m dolomite rhombs. Restricted lagoonal evaporitic environment. MF13, ulb/sed 8991-11, sample SG-48, Fromelennes Fm. 

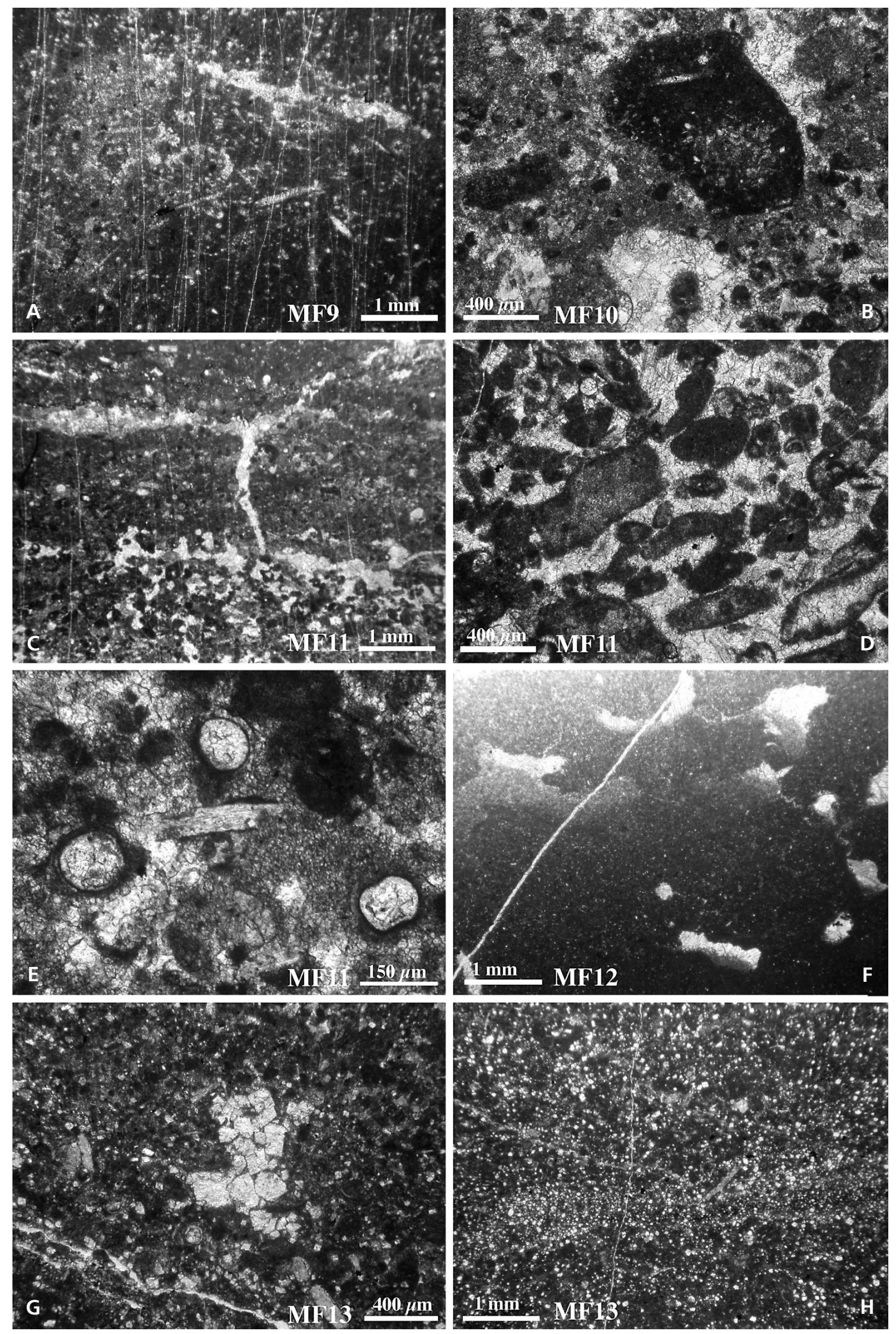
Some of these specimens have been figured by Milhau (1982, 1983a, b) from the Sourd d'Ave section.

The Givet Group/Frasnes Group transition has been recently investigated for ostracods in the Dinant Synclinorium by Casier \& Préat (2009) at Nismes, $42 \mathrm{~km}$ west of the Sourd d'Ave, and by Maillet (2010) in the Flohimont section at Fromelennes, $22 \mathrm{~km}$ west of the Sourd d'Ave. The great abundance of ostracods in the upper part of the Fromelennes Fm. in these two sections prompted us to undertake the study of ostracods present in this formation at Sourd d'Ave.

\section{Material and methods}

For our study, 47 new samples of approximately $500 \mathrm{~g}$ each were collected in the Sourd d'Ave section, 8 in the Moulin Boreux Mbr, 36 in the Fort Hulobiet Mbr, and 3 in the Pont d'Avignon Mbr. All the samples were crushed by a hydraulic press and about $200 \mathrm{~g}$ of each sample (except SA-38 and SA-39: 300 g; SA-35 and SA-36: $400 \mathrm{~g}$ ) were processed with $99.8 \%$ glacial acetic acid, at nearly $90^{\circ} \mathrm{C}$, for four days at a rate of eight hours a day. This mode of extraction, called the hot acetolysis method, was described by Lethiers \& Crasquin-Soleau (1988). The residues were sieved on $250 \mu \mathrm{m}$ and 1,600 $\mu \mathrm{m}$ mesh screens. About 1,130 carapaces, valves and fragments of ostracods identifiable at any taxonomic level were thus extracted, 50 in the Moulin Boreux Mbr, 915 in the Fort Hulobiet Mbr, and 165 in the Pont d'Avignon Mbr. The stratigraphic positions of these new ostracod samples are shown on Fig. 4.

About 500 ostracods collected by Milhau (1983a) in the Fromelennes Fm. at Sourd d'Ave, and stored in the collection of the Faculté Libre des Sciences et Technologies de Lille, were also reviewed. The approximate location of the samples of Milhau is the following: Sc119 is slightly below the new sample SA-45 (Fig. 4); Sc-120 corresponds approximately to SA-43; Sc121 is between SA-40 and SA-39; Sc-123 corresponds approximately to SA-22, and Sc-124 to SA-15.

\section{Paleoecology of ostracods in the Sourd d'Ave section}

The distribution of ostracods is extremely variable in the Sourd d'Ave section. Sixteen samples out of the 44 recently collected in the Fromelennes Fm. are unproductive (SA-42, 31, 29, 25-23, 20, 18, 17, 13, 10, 9, 7-4). In this formation, ostracods are rare or even very rare in all the other samples with the exception of the very rich samples SA-39 to SA-35. Ostracods are present but indeterminable in samples SA-46, 30, 26, 14, and from sample SA-46 to sample SA-41 ostracods are coated.

Ostracods are abundant in the samples collected in the Pont d'Avignon Mbr, and relatively rare in the other members belonging to the Nismes Fm. Their distribution in the Fromelennes Fm. at Sourd d'Ave is reported in Table 2. For the Nismes Fm., see Fig. 2 in Casier (1987a).

Ostracods in the Sourd d'Ave section belong exclusively to the Eifelian Mega-Assemblage, which corresponds to the incorrectly named "Eifelian ecotype" of Becker (in Bandel \& Becker 1975; see Casier 2004). Several assemblages are recognized in the Eifelian Mega-Assemblage, and they are indicative of lagoonal, semi-restricted, agitated marine environments above fair-weather wave base, and marine environments below fair-weather wave base or below storm wave base (see Casier 1987b, fig. 1 in Casier 2008, fig. 3 in Casier \& Préat 2003). In this last assemblage, the abundance of alleged filter-feeding metacopids (Adamczak 1969, Lethiers \& Whatley 1995) comparative to deposit-feeding podocopids is related to the oxygen content of the bottom waters and consequently to the water depth. In deeper settings, only metacopid and palaeocopid ostracods are present, and in this case the ostracod assemblage corresponds to the Malvinokaffric "ecotype" of Lethiers et al. (2001) as demonstrated by the recent study of ostracods from the Belen Fm. at Pisacavina, in Bolivia (Casier in Racheboeuf et al. 2012).

In the Fromelennes Fm. (Givet Group) (Table 2, Figs 8-10, Annex 1), 44 species are identified in the Fromelennes Fm.: 13 belong to the Palaeocopina, 2 to the Paraparchiticopina, 10 to the Platycopina, 5 to the

Figure 8. Palaeocopina and Parachiticopina present in the Fromelennes Fm. at Sourd d'Ave. The types are deposited in the collections of the Department of Paleontology (section Micropaleontology) of the Royal Belgian Institute of natural Sciences (IRScNB No. b 64...). • A - Amphissites sp. indet. SA-37, IRScNB No. b 6443, right valve, $\times$ 80. • B - Kozlowskiella plana (Kummerow, 1953). SA-28, IRScNB No. b 6444, right valve, $\times$ 50. - C - Aparchitellina irgizlensis Rozhdestvenskaya, 1962. SA-43, IRScNB No. b 6445, right lateral view of a carapace, $\times 60$. $\bullet$ D - Aparchitellina aff. glabra Rozhdestvenskaya, 1962. SA-35, IRScNB No. b 6446, right valve, $\times 85$. $\bullet$ E - Kozlowskiella sp. indet. SA-41, IRScNB No. b 6447, broken left valve, $\times 40 . \bullet \mathrm{F}-$ Nodella faceta Rozhdestvenskaya, 1972. SA-124, IRScNB No. b 6448, right valve, $\times 85$. $\bullet$ G - Fellerites $\mathrm{sp}$. indet. SA-35, IRScNB No. b 6449 , broken valve, $\times 50 . \cdot \mathrm{H}-$ Parapribylites $\mathrm{cf}$. cingulatus (Kummerow, 1953). SA-35, IRScNB No. b 6450, right lateral view of a carapace, $\times 110$. - I-Kielciella fastigans (Becker, 1964). SA-35, IRScNB No. b 6451, right lateral view of a carapace, $\times 60$. $\bullet$ J - Gravia? sp. indet. SA-37, IRScNB No. b 6452 , left lateral view of a carapace, $\times 90 . \bullet \mathrm{K}-$ Coryellina? sp. indet. SA-37, IRScNB No. b 6453, right lateral view of a carapace, $\times 70$. $\bullet$ L - Buregia ovata (Kummerow, 1953). SA-16, IRScNB No. b 6454, right lateral view of a carapace, $\times 50$. $・$ M - Youngiella sp. indet. SA-11, IRScNB No. b 6455, right lateral view of a poorly preserved carapace, $\times 60 . \cdot \mathrm{N}-$ Coeloenellina optata (Polenova, 1955). SA-47, IRScNB No. b 6456, right lateral view of a carapace, $\times 65 . \cdot \mathrm{O}-$ Coeloenellina sp. indet. SA-35, IRScNB No. b 6457, right lateral view of a carapace, $\times 85$. 

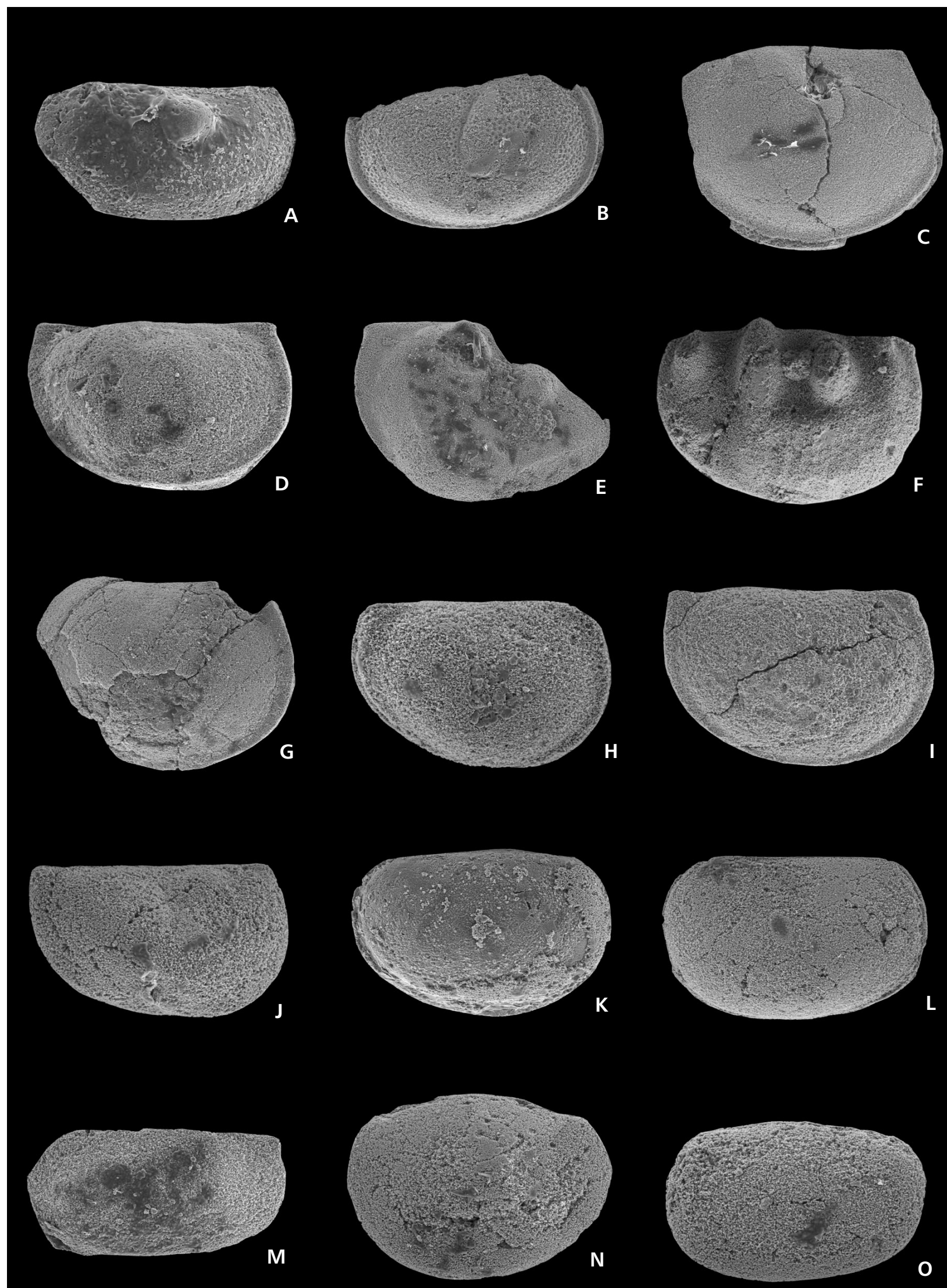
Table 2. Distribution of ostracods in the Fromelennes Fm. exposed in the Sourd d'Ave section at Ave-et-Auffe. Samples 119-124 from Milhau (1983). \begin{tabular}{lllllllllllllllllllllllllllll}
\hline SOURD D'AVE & 47 & 119 & 45 & 44 & 43 & 120 & 41 & 40 & 121 & 39 & 38 & 37 & 36 & 35 & 34 & 33 & 32 & 28 & 27 & 123 & 21 & 19 & 16 & 15 & 124 & 12 & 11 & 8
\end{tabular} Kozlowskiella sp. indet.

Coeloenellina optata (Polenova, 1955) $*$

(Polenova, 1955) $\quad * \quad ?$

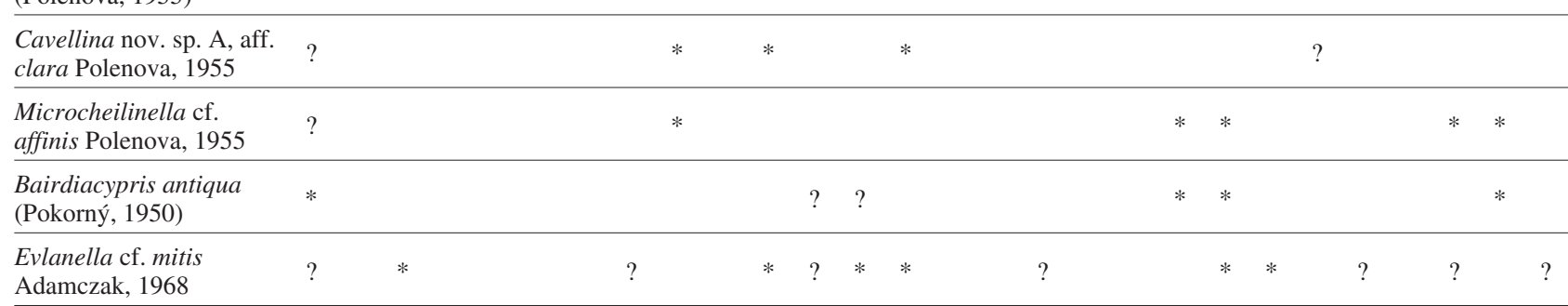
Adamczak, 1968

Cytherellina obliqua

(Kummerow, 1953)

"Schneideria" groosae (Becker, 1971)

Uchtovia abundans (Pokorný, 1950)

Cryptophyllus sp. 3 in

Magne (1964)

Aparchitellina irgizlensis

Rohdestvenskaya, 1962

Quasillitidae gen. and sp.

indet.

Cryptophyllus sp., aff. materni Becker, 1971

Acratia lucea Maillet nom. nud.

Polyzygia neodevonica

(Matern, 1929)

Cytherellina sp. A, aff.

perlonga (Kummerow,

1953)

Orthocypris kummerowi

Zbikowska, 1983?

Knoxiella? sp. A

Bairdia paffrathensis

Kummerow, 1953

Bairdia cf. siliklensis

Rozhdestvenskaya, 1962

Uchtovia refrathensis

(Krömmelbein, 1954)

Cavellina macella

Kummerow, 1953

Orthocypris? bicarinata

Maillet nom. nud.

Nodella faceta

Rozhdestvenskaya, 1972

Evlanella germannica

Becker, 1964

Poloniella sp. indet.

Acratia sp. A, aff. sp. G II

in Magne (1964)

Gravia? sp. indet.

Amphissites sp. indet.

\begin{tabular}{lllllllllllllll}
$*$ & $*$ & $*$ & & & & & & & & \\
$*$ & & $*$ & & $*$ & & $*$ & $*$ & $*$ & \\
$*$ & $*$ & $*$ & $*$ & $*$ & $*$ & $*$ & & $*$ & & \\
\hline
\end{tabular}

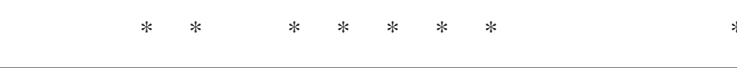


Table 2. continued

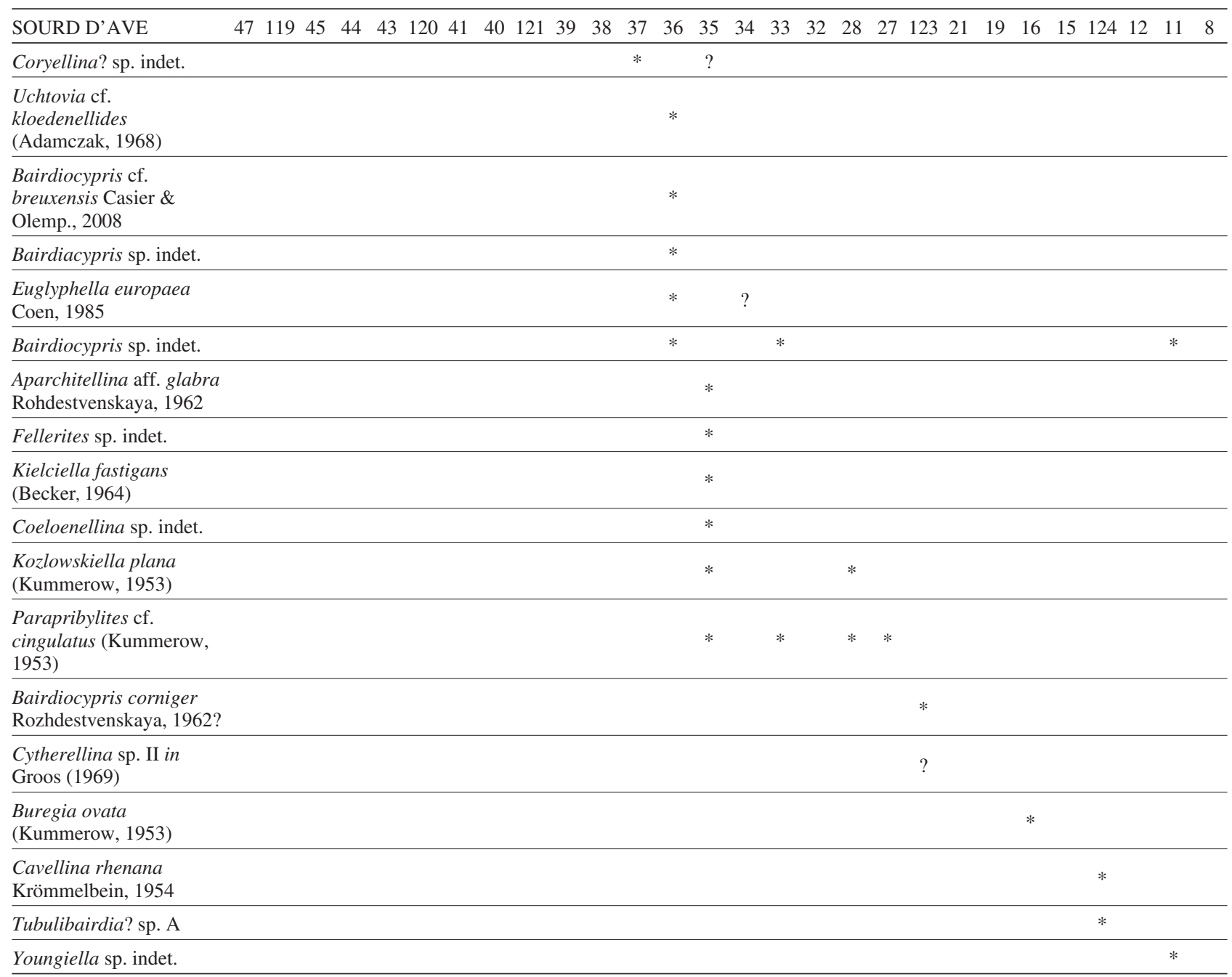

Metacopina, 12 to the Podocopina and 2 to the Eridostraca. In the Moulin Boreux Mbr, ostracods are generally poorly preserved and frequently coated by algae (particularly from samples SA-46 to SA-44). This is indicative of a relatively agitated shallow marine environment (oolitic facies). Ostracods in sample SA-46 are indeterminable, but in samples SA-45 and SA-44, the monospecificity indicative of semi-restricted water conditions predominates with the genus Cryptophyllus. In the base of the Fort Hulobiet Mbr (from sample SA-121 to SA-35), a more diversified rich fauna and the presence among others of Bairdia paffrathensis Kummerow, 1953, and Polyzygia neodevonica (Matern 1929), are indicative of open marine water conditions below fair-weather wave base. In the middle and especially in the upper part of the Fort Hulobiet Mbr, ostracods are absent in several samples (SA-18, 17, 10, 9, 7 to 4). This is probably indicative of more stressfull lagoonal conditions related to an increase of the aridity of the climate in the Late Givetian. Nevertheless these lagoonal conditions are sometimes interrupted by semi-restricted water conditions (SA-34, 32) and even by agitated marine episodes (SA-33, 123, 21).

The Givet Group/Frasnes Group transition is abrupt in the Sourd d'Ave section: the environment becomes exclusively marine. Twenty-nine species are identified in the Nismes Fm. (fig. 2 in Casier 1987a, and plates 1, 2, ibid.), 5 belong to the Palaeocopina, 5 to the Platycopina, 8 to the Metacopina, 9 to the Podocopina and 2 to the Eridostraca.

In the Pont d'Avignon Mbr we have identified: Roundyella patagiata (Becker, 1964), Uchtovia refrathensis (Krömmelbein, 1954), Cavellina sp. A, aff. clara Polenova, 1955, Samarella? sp. A, Quasillites cf. nismesensis Casier, 2009, Jenningsina paffrathensis Krömmelbein, 1954, Polyzygia beckmanni beckmanni Krömmelbein, 1954, Cytherellina sp. A, aff. perlonga (Kummerow, 1953), Orthocypris kummerowi Zbikowska, 1983, Bairdiocypris cf. breuxensis Casier \& Olempska, 2008, Acratia sp., aff. GII in Magne, 1964, Bairdia paffrathensis, 
Kummerow, 1953, Bairdia cf. carinata Polenova, 1960, Bairdia singularis Krömmelbein, 1954, Cryptophyllus sp. nov., aff. granulifera (Adamczak, 1961). This ostracod assemblage corresponds to a well oxygenated marine environment below fair-weather wave base.

In the Sourd d'Ave Mbr, Casier (fig. 2 in Casier 1987a) recorded the presence of Nodella hamata Becker, 1971, Nodella sp. indet, Balantoides minimus (Lethiers, 1970), Refrathella sp. indet., Scrobicula? sp. indet., Uchtovia refrathensis (Krömmelbein, 1954), Uchtovia materni Becker, 1971?, Cavellina sp. A, aff. clara (Polenova, 1955), Cavellina cf. caduca Mc Gill, 1963, Cavellina sp., Polyzygia beckmanni beckmanni Krömmelbein, 1954, Ponderodictya belliloci Casier, 1986, Jenningsina paffrathensis Krömmelbein, 1954, Favulella lecomptei Becker, 1971, Asturiella blessi Becker, 1971?, Bairdiocypris sp., Baschkirina? sp. and Cryptophyllus sp. indet. This ostracod assemblage is also indicative of an open marine environment, but of greater depth as displayed by the abundance of metacopids comparative to podocopids.

In the base of the La Prée Mbr ostracods became rarer, associated with deepening. Casier (1987a) reported the presence of Amphissites sp., Adelphobolbina europaea Becker, 1971, Uchtovia materni Becker, 1971, Favulella lecomptei Becker, 1971, Ponderodictya belliloci Casier, 1986, Jenningsina lethiersi Becker, 1971 vel J. paffrathensis Krömmelbein, 1954, Bairdia sp. and Cryptophyllus sp.

Finally in the section lateral but higher extension of the Sourd d'Ave section, Casier (fig. 3 in Casier 1987a) recorded several ostracods and among them entomozoid ostracods (Franklinella) belonging to the Myodocopid Mega-Assemblage, a proxy for hypoxic water conditions (Casier 2004). However the exact dating of this section is controversial. Casier (1987a) suggests that this section exposes the boundary between the Nismes Fm. and the overlaying Moulin Liénaux Fm., but Bultynck \& Coen in Boulvain et al. (1999) assigned this section to the Ermitage Mbr, the second member in the Moulin Liénaux Fm. The presence of Franklinella latesulcata Paeckelmann, 1921, in the base of this section should indicate that the torleyi Zone of the biostratigraphic zonation established on entomozoid ostracods by Rabien (1954), and corresponding to the Lower Polygnathus asymmetricus conodont Zone (Groos-Uffenorde \& Wang 1989), is recognized at Sourd d'Ave. Consequently, we can surmise that in reality the top of the Chalon Mbr (15 m of shales), the first member belonging to the Moulin Liénaux Fm., the Arche Mbr (reduced to $6 \mathrm{~m}$ of limestones, nodular limestones and shales with calcaro-argilaceous nodules in which Bouharrak (1984) has collected conodonts characteristic of the Polygnathus asymmetricus Zone), and the base of the Ermitage Mbr (31 m of shales), are exposed in this second section.

Two zones of the zonal sequence established on metacopid ostracods by Casier (1979, see also 2008) and following those of Lethiers (1974a), are recognized in the Nismes Fm. at Sourd d'Ave: The Polyzygia beckmanni beckmanni Zone and the Favulella lecomptei Zone (Casier 1987a), but the rarity of ostracods in the middle part of the Sourd d'Ave Mbr does not permit the precise placement of the base of this last zone.

\section{Comparison with the Nismes and Flohimont sections}

The Givet Group/Frasnes Group transition has been recently studied at Nismes, close to Frasnes, by Casier \& Préat (2009), and at Flohimont, close to Givet, by Maillet (2010). The only significant difference based on the ostracod fauna and the sedimentology in the three sections is the transition from lagoonal to open-marine environments close to the Givet Group/Frasnes Group boundary. But at Sourd d'Ave, this change is abrupt and takes place exactly at this boundary. On the contrary in the Nismes and Flohimont sections, this change corresponds to the entry of Polyzygia beckmanni beckmanni Krömmelbein, 1954, and occurred in the upper part of the Fromelennes Fm. In reality there is a hiatus emphasized by an irregular contact at the Givet Group/Frasnes Group boundary in the Sourd d'Ave section (Bultynck \& Coen in Boulvain et al. 1999).

Figure 9. Platycopina, Metacopina and Podocopina present in the Fromelennes Fm. at Sourd d'Ave. • A - Cavellina sp. A, aff. clara Polenova, 1955. SA-35, IRScNB No. b 6458, left lateral view of a carapace, $\times 65$. • B - Cavellina rhenana Krömmelbein, 1954. SA-124, IRScNB No. b 6459, left lateral view of a broken carapace, $\times 75$. $-\mathrm{C}-$ Cavellina macella Kummerow, 1953. SA-39, IRScNB No. b 6460, left lateral view of a carapace, $\times 45$. - D - Uchtovia abundans (Pokorný, 1950). SA-123, IRScNB No. b 6461, left lateral view of a carapace, $\times 50$. $・$ E - Uchtovia refrathensis $($ Krömmelbein, 1954). SA-38, IRScNB No. b 6462, left lateral view of a carapace, $\times 60$. • F - Uchtovia cf. kloedenellides (Adamczak, 1968). SA-6, IRScNB No. b 6463, left lateral view of a carapace, $\times 50$. $\bullet$ G - Evlanella germanica Becker, 1964. SA-35, IRScNB No. b 6464, left lateral view of a carapace, $\times 55$. - H - Evlanella cf. mitis Adamczak, 1968. SA-45, IRScNB No. b 6465, left lateral view of a broken carapace, $\times 40$. $\bullet$ I - Knoxiella? sp. A. SA-121, IRScNB No. b 6466, left lateral view of a carapace, $\times 85$. $\mathrm{J}-$ Cytherellina obliqua (Kummerow, 1953). SA-39, IRScNB No. b 6467, right lateral view of a carapace, $\times 90$. $\bullet \mathrm{K}-$ Cytherellina sp. II in Groos (1969)?. SA-21, IRScNB No. b 6468, right lateral view of a carapace, $\times 35$. $\bullet$ L - Cytherellina sp. A, aff. perlonga (Kummerow, 1953). SA-39, IRScNB No. b 6469, right lateral view of a carapace, $\times 70$. $\bullet$ M - Polyzygia neodevonica (Matern, 1929). SA-36, IRScNB No. b 6470, right lateral view of a carapace, $\times 65 . \cdot \mathrm{N}-$ Euglyphella europaea Coen, 1985. SA-36, IRScNB No. b 6471, right lateral view of a carapace, $\times 65 \cdot$ O - Acratia lucea Maillet, nom. nud. SA-39, IRScNB No. b 6472, right lateral view of a carapace, $\times 60$. 

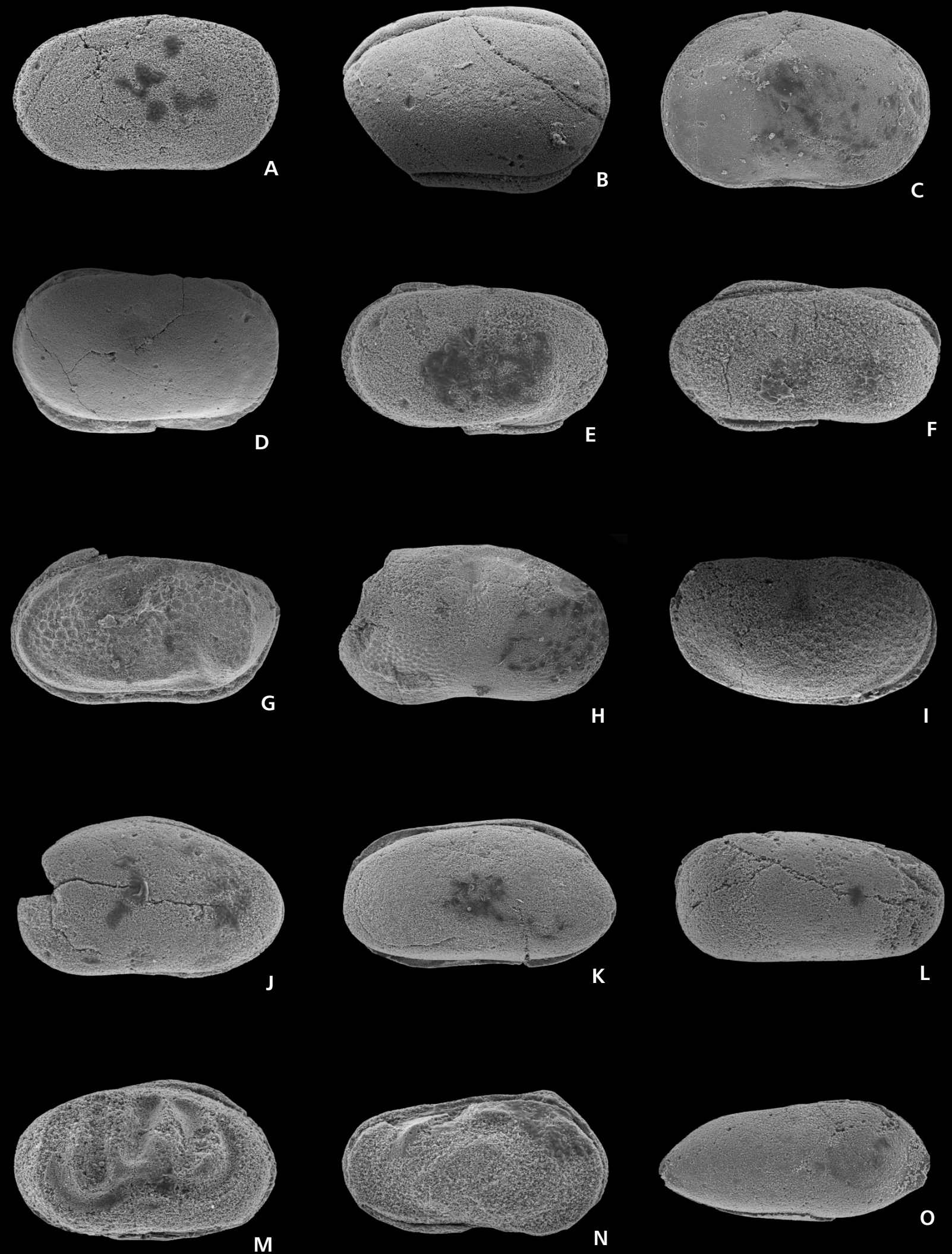


\section{Geographic distribution of species recognized close to the G/F transition at Sourd d'Ave}

Shared relationships between the Ardenne and North America are restricted to generic level (Coen 1985) and are found mainly amongst the cosmopolitan Thlipsuroidea (Polyzygia, Jenningsina...).

Relationships between the Ardenne and North Africa are more important. Numerous genera of palaeocopid, platycopid, metacopid and podocopid ostracods are common in both regions but only rarely are species observed in the Frasnian of the Sourd d'Ave section recognized in Algeria (Magne 1964, Lefèvre 1971, Casier 1985) and in Morocco (Milhau 1996; Casier et al. 1997, 2010). They belong mainly to the Thlipsuroidea (Polyzygia neodevonica, P. beckmanni beckmanni, Favulella lecomptei, Uchtovia abundans).

Relationships with Asia are also restricted to genera except for the Eastern Taurides (Turkey) where studies in progress by Nazik (Nazik \& Becker 2008, Nazik et al. 2012) show important similarities. Several species present in the Frasnian of the Sourd d'Ave section (Adelphobolbina europaea, Uchtovia refrathensis, U. materni, Polyzygia neodevonica, P. beckmanni beckmanni and Bairdia paffrathensis) are common with that region.

Relationships with Spain and the southern part of France that was united with Gondwana during the Devonian are also restricted to the generic level, except for rare species belonging to Thlipsuroidea: Favulella lecomptei and Polyzygia neodevonica are recognized in Spain by Gozalo (1994) and this last species is also present in the G/F GSSP at Puech de la Suque (Montagne Noire). However ostracods are generally represented by instars difficult to identify in the G/F GSSP, which is largely composed of storm deposits (Casier \& Préat 2007).

The European sections studied from Boulonnais (France) to the Holy Cross Mountains (Poland) form a province in which the fauna present maximum affinities (Coen, 1985). This province corresponds to the ancient Rhenohercynian carbonate platform. Numerous papers have been published on these sections, among others by Kummerow (1953), Krömmelbein (1954), Magne (1964), Becker (1964, 1965a, b), Adamczak (1968, 1976), Groos (1969), Lethiers (1970, 1982, 1984), Olempska (1979), Zbikowska (1983), Milhau (1982, 1983a, 1983b, 1988). In this province, relationships with the Boulonnais (France), and with the Eifel and the Bergisches Land (Germany) are the most important. Twenty-three species recognized in the Sourd d'Ave section are known from the Boulonnais, 17 from the Eifel and the Bergisches Land (Germany), and 12 from the Holy Cross Mountains (Poland).

The species common with the Boulonnais are the following: Adelphobolbina europaea, Balantoides minimus, Roundyella patagiata, Kielciella fastigans, Buregia ovata, Cavellina rhenana, Uchtovia abundans, U. materni, Evla- nella germanica, Cytherellina obliqua, Asturiella blessi, Favulella lecomptei, Jenningsina lethiersi, J. paffrathensis, Polyzygia neodevonica, P. beckmanni beckmanni, Ponderodictya belliloci, Microcheilinella cf. affinis, Orthocypris? bicarinata, Acratia lucea, Bairdia paffrathensis, Bairdiacypris antiqua and Cryptophyllus sp. 3.

The species common with Germany are the following: Kozlowskiella plana, Roundyella patagiata, Nodella hamata, Kielciella fastigans, Buregia ovata, Cavellina rhenana, C. macella, Uchtovia abundans, U. refrathensis, $U$. materni, Evlanella germanica, Cytherellina obliqua, Polyzygia neodevonica, P. beckmanni beckmanni, Jenningsina paffrathensis, Bairdia paffrathensis and Bairdia singularis.

The species common with the Holy Cross Mountains are the following: Adelphobolbina europaea, Kielciella fastigans, Cavellina macella, Uchtovia refrathensis, U. abundans, U. materni, Orthocypris kummerowi, Bairdia paffrathensis, Bairdiacypris antiqua, Favulella lecomptei, Asturiella blessi and Jenningsina lethiersi.

Several genera present in the Sourd d'Ave section are recognized in Moravia (Czech Republic) but only Uchtovia abundans and Bairdiacypris antiqua are common (Pokorný 1950). The relationship to the Russian Platform is also limited to Aparchitellina irgizlensis, Nodella faceta and Coeloenellina optata described by Rozhdestvenskaya (1962) and Polenova (1955) from the Volga and Ural districts.

\section{The Frasnes Event and the ostracod fauna in Europe}

Conversely to Frasnian ostracods, Givetian ostracods have been the theme of numerous papers, mostly reflecting the predominant lithologies of the two stages, which is generally carbonaceous in the Givetian, and shaly in the Frasnian in most European sections. Ostracods are more abundant and well preserved in limestones where they can be extracted by the hot acetolysis method (Lethiers \& Crasquin-Soleau 1988), and more rare and poorly preserved in shales. Studies of ostracods present in sections straddling the G/F boundary are also rare. Nevertheless a clear faunal change among the benthic ostracod communities is distinguishable close to the G/F boundary in several European countries. Ostracods from the Boulonnais, in the western extension of the Namur Synclinorium of the Ardenne, have been studied by Magne (1964), Lethiers (1982) and Milhau (1983a, 1983b, 1988). Although the G/F interval is faulted in this area, Milhau (1983b) reported 47 ostracod species in the Givetian Blacourt Fm. (Middle P. varcus conodont Zone) and 9 in the Frasnian Beaulieu Fm. (Lower L. asymmetricus conodont Zone), of which only 1 straddles the G/F boundary. In the Rheinische Schiefergebirge, where ostracods have been studied e.g. by Groos (1969) 


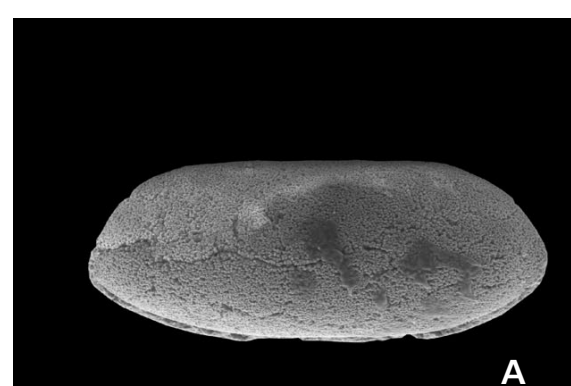

A

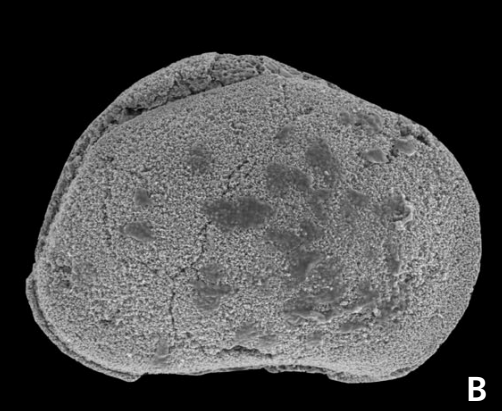

B

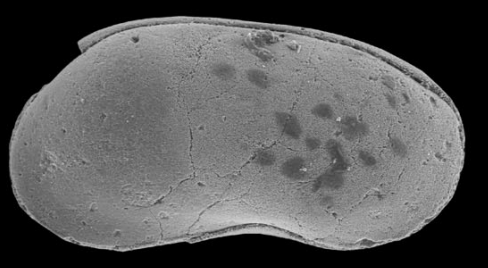

D

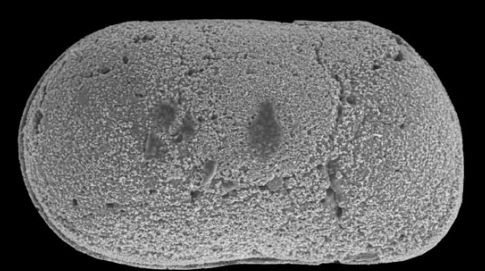

E

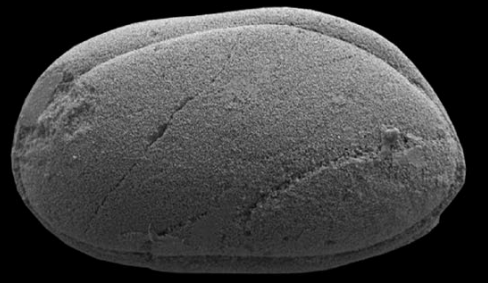

$\mathbf{F}$

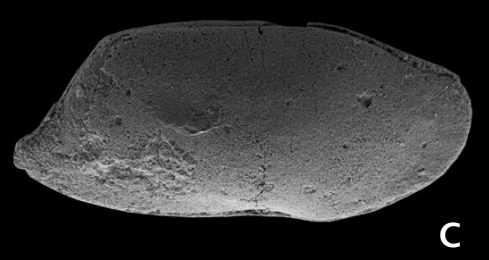

C

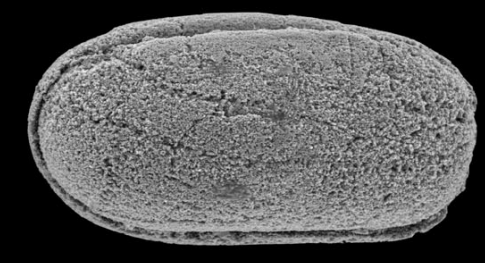

G

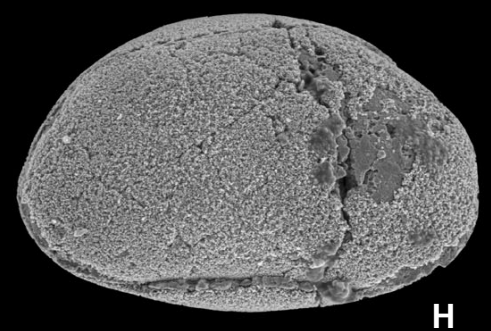

H
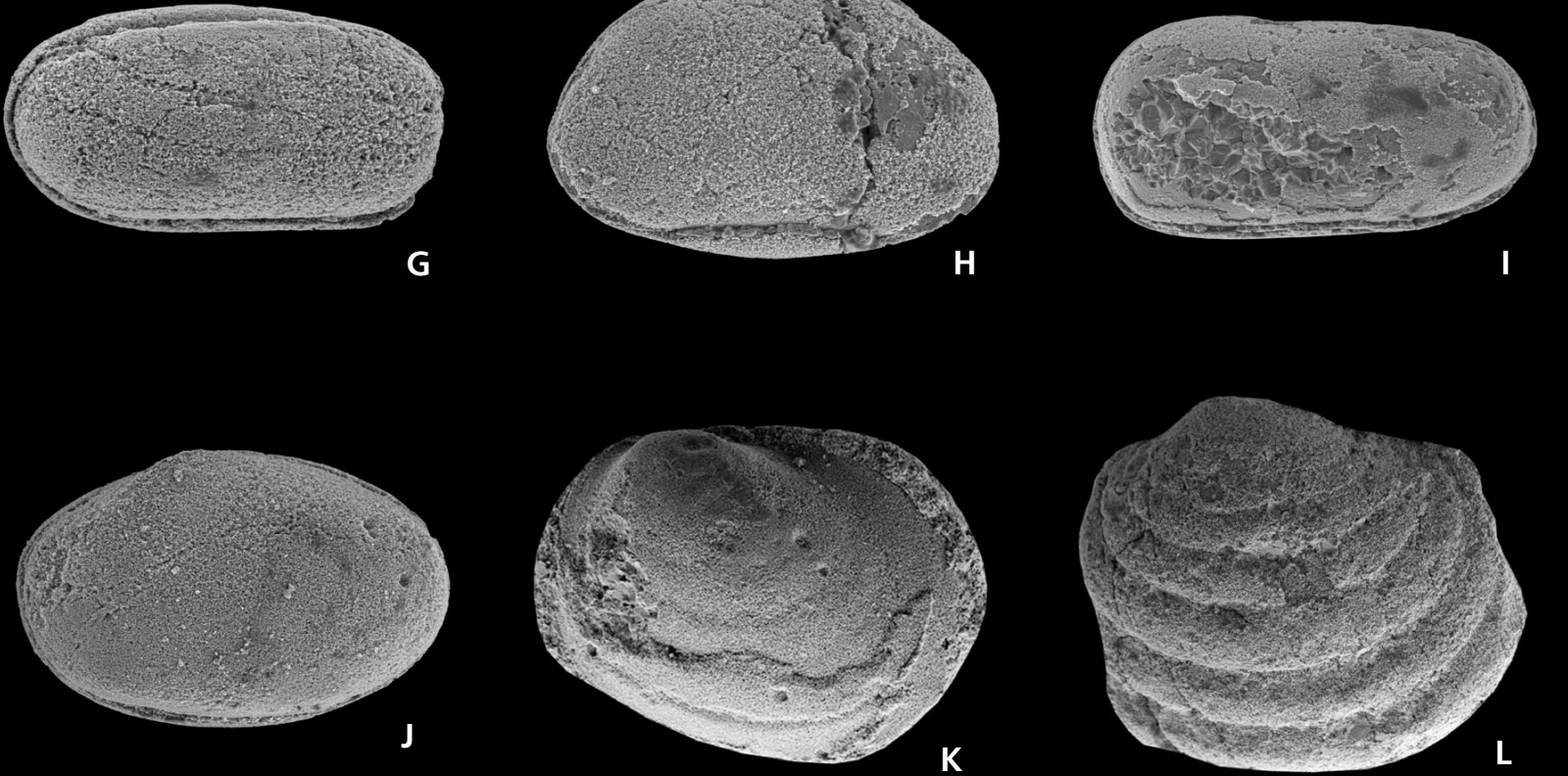

Figure 10. Podocopina (continuation) and Eridostraca present in the Fromelennes Fm. at Sourd d'Ave. $-\mathrm{A}-$ Acratia sp. A, aff. sp. G II in Magne (1964). SA-38, IRScNB No. b 6473, right lateral view of a carapace, $\times 65$ • • B - Bairdia cf. siliklensis Rozhdestvenskaya, 1962. SA-11, IRScNB No. b 6474 , right lateral view of a carapace, $\times 65 . \bullet$ C - Bairdia paffrathensis Kummerow, 1953. SA-121, IRScNB No. b 6475, right lateral view of a carapace, $\times 50 . \bullet \mathrm{D}-$ Bairdiacypris antiqua (Pokorný, 1950). SA-47, IRScNB No. b 6476, right lateral view of a carapace, $\times 45$. $・ \mathrm{E}-$ "Schneideria" groosae (Becker, 1971). SA-35, IRScNB No. b 6477, right lateral view of a carapace, $\times 80$. $\bullet$ F - Tubulibairdia? sp. A. SA-124, IRScNB No. b 6478, right lateral view of a carapace, $\times 80 . \cdot \mathrm{G}-$ Microcheilinella cf. affinis Polenova, 1955. SA-21, IRScNB No. b 6479, right lateral view of a carapace, $\times 85$. $\bullet \mathrm{H}-$ Bairdiocypris cf. breuxensis Casier \& Olempska, 2008. SA-36, IRScNB No. b 6480, right lateral view of a carapace, $\times 90$. $\bullet$ I - Orthocypris kummerowi Zbikowska, 1983?. SA-39, IRScNB No. b 6481, right lateral view of a carapace, $\times 70$. $\bullet$ - Orthocypris? bicarinata Maillet nom. nud. SA-39, IRScNB No. b 6482, right lateral view of a carapace, $\times 85$. $\bullet$ K Cryptophyllus sp. 3 in Magne (1964). SA-120, IRScNB No. b 6483, left lateral view of a carapace, $\times 90$. $\bullet$ L - Cryptophyllus sp., aff. materni Becker, 1971. SA-121, IRScNB No. b 6484, left valve, $\times 80$. 
and Becker (1971a, 1971b), the number of species straddling the $\mathrm{G} / \mathrm{F}$ boundary is also insignificant. In the southern part of the Holy Cross Mountains, Malec \& Racki (1993) reported only 2 species straddling the G/F boundary.

The widespread faunal change around the Middle/Upper Devonian boundary is related to the Frasnes event (House 1985). The benthic ostracod communities of the Rhenohercynian platform are significantly affected by this event, with the installation of a Frasnian cosmopolitan fauna dominated by metacopid and palaeocopid ostracods replacing the endemic faunas of the Givetian that are dominated by platycopid and podocopid ostracods. This change is coupled with an important sea-level rise and a climatic change. The climate becomes warmer and more arid from the end of the Givetian onwards (Joachimski et al. 2009, Marshall et al. 2011), inducing continental erosion responsible for a higher detrital influx in the marine realm. In the same way, a major transgressive phase at the G/F boundary (Boulvain et al. 2009) leads to the flooding of the Givetian carbonate platform (Préat \& Mamet 1989) and to the disappearance of the Givetian large reef barriers.

\section{Conclusions}

Ostracods belong exclusively to the Eifelian MegaAssemblage in the Sourd d'Ave section. Forty-four species have been identified in the Givet Group and 25 in the Frasnes Group. These ostracods are successively indicative of semi-restricted water conditions in the upper part of the Moulin Boreux Mbr, of marine environments below fairweather wave base in the base of the Fort Hulobiet Mbr, and of lagoonal environments interrupted by brief semi-restricted or marine agitated episodes in the middle and upper part of this last member. The Givet Group/Frasnes Group transition is abrupt at Sourd d'Ave: the environment became open marine and the relative proportion of podocopids and metacopids indicates increasing water depth in the Early Frasnian. This change corresponds to the entry of Polyzygia beckmanni beckmanni, and occurred in the top of the Fromelennes Fm. in other sections of the Dinant Synclinorium.

Based on the study of Sourd d'Ave and Nismes sections (Casier \& Préat 2009), only 12 (13?) out of 56 species identified in the Late Givetian survived the Frasnes Event (House 1985) in the studied section. The change in environmental conditions at the Givet Group/Frasnes Group boundary from semi-restricted to open marine water conditions is mostly responsible for this transformation. The surviving species belong principally to metacopids and palaeocopids.

Sedimentological and ostracod analyses are in agreement, with greater ostracod diversity found in more open facies (MF1-3) in the shaly intervals of the Fort Hulobiet Mbr and in the whole of the Nismes Fm., while only rare ostracods have been observed in the most stressful environments
(MF9-13) in most of the Givetian succession. Typical ostracods of semi-restricted environments (MF6) and of higher energy settings (MF7) have also been observed in the Givetian succession. The boundary between the Givet Group and the Frasnes Group is characterized by a dramatic deepening from restricted evaporative lagoonal facies (microfacies 6-13) to open marine interbedded marly shales and nodular limestones (microfacies 1-3). The upper part of the Fort Hulobiet Mbr consists of interbedded biostromes (semi-restricted stromatoporoid boundstones) followed by Amphipora floatstones, then of fossil-poor units and restricted supratidal laminites with well-developed fenestral fabrics. The Frasnian Pont d'Avignon Mbr shows a rich faunal assemblage (bryozoans brachiopods, molluscs, nautiloids, tentaculitids, ostracods) suggesting an abrupt drowning from the marginal Givetian carbonate platform into a Frasnian distal ramp setting or deep basinal environment below or near the storm wave base. This transgressive event at the $\mathrm{G} / \mathrm{F}$ boundary is highlighted by argillaceous shales, marly shales and tempestites with open-marine interbedded nodular limestones, and the development of a rich fauna succeeding the endemic communities that prevailed during Givetian times.

\section{Acknowledgments}

The research is a contribution to the IGCP 596 project. We thank especially Bruno Milhau (Faculté Libre des Sciences et Technologies, Université Catholique de Lille), who reviewed our manuscript and allowed us to re-examine the ostracods collected by him in the Sourd d'Ave section. We are also very grateful to David Bond (University of Leeds) who improved substantially the spelling of our manuscript and for his constructive remarks.

\section{References}

AdamczaK, F. 1961. On the genus Poloniella Guerich (Ostracoda). Acta Paleontologica Polonica 6(3), 283-320.

AdamcZaK, F. 1968. Palaeocopa and Platycopa (Ostracoda) from Middle Devonian rocks in the Holy Cross Mountains, Poland. Stockholm Contributions in Geology 17, 1-109.

AdAMCZAK, F. 1969. On the question of whether the paleocope ostracods were filter-feeders, 93-98. In NEALE, J.W. (ed.) The taxonomy, morphology and ecology of recent ostracoda. Oliver and Boyd, Edinburgh.

AdAMCZAK, F. 1976. Middle Devonian Podocopida (Ostracoda) from Poland; their morphology, systematics and occurrence. Senckenbergiana lethaea 57(4-6), 265-467.

Aigner, T. 1985. Storm depositional systems. Coated Lecture Notes in Earth Science 3, 1-174. Springer Verlag, Berlin.

BANDEL, K. \& BECKER, G. 1975. Ostracoden aus paläozoischen pelagischen Kalken der Karnischen Alpen (Silurium bis Unterkarbon). Senckenbergiana lethaea 56(1), 1-83.

BeCKER, G. 1964. Palaeocopida (Ostracoda) aus dem Mitteldevon der Sötenicher Mulde (N-Eifel). Senckenbergiana lethaea 45(1-4), 43-113. 
BeCKer, G. 1965a. Podocopida (Ostracoda) aus dem Mitteldevon der Sötenicher Mulde (N-Eifel). Senckenbergiana lethaea 46(4-6), 367-441.

BECKER, G. 1965b. Revision Kummerow'scher Otracodenarten aus dem deutschen Mitteldevon. Fortschritte in der Geologie von Rheinland und Westfalen 9, 151-188.

BECKeR, G. 1971. Ostracoda aus dem Mittel-Frasnium (Oberdevon) der Mulde von Dinant. Bulletin de l'Institut royal des Sciences naturelles de Belgique 47(34), 1-82.

Berdan, J. \& Sohn, I. 1961. Family Pachydomellidae Berdan \& Sohn, n. fam., 373-374. In Moore, R. (ed.) Treatise on Invertebrate Paleontology. Part Q. Arthropoda 3, Crustacea, Ostracoda. Geological Society of America \& University of Kansas Press, Boulder \& Lawrence.

BOUHARRAK, M. 1984. Lithostratigrafie and biostratigrafie (Conodonten) en structuur van het Boven Givetiaan en het Frasniaan in het gebied van Ave-et-Auffe. 102 pp. Unpublished bachelor in Sciences, Katholieke Universiteit Leuven, Belgium.

Boulvain, F., Bultynck, P., Coen, M., Coen-Aubert, M., Lacroix, D., Laloux, M., Casier, J.-G., Dejonghe, L., Dumoulin, V., Ghysel, P., Godefroid, J., Helsen, S., MouraviefF, N., Sartenaer, P., Tourneur, F. \& Vanguestaine, M. 1999. Les formations du Frasnien de la Belgique. Memoirs of the Geological Survey of Belgium 44, 1-126.

Boulvain, F., Mabille, C., Poulain, G. \& Da Silva, A.-C. 2009. Towards a palaeogeographical and sequential framework for the Givetian of Belgium. Geologica Belgica 12, 161-178.

Boulvain, F. \& PrÉAt, A. 1987. Les calcaires laminaires du Givétien Supérieur du bord sud du Bassin de Dinant (Belgique, France). Témoins d'une évolution paléoclimatique. Annales de la Société géologique de Belgique 109, 609-619.

Bultynck, P. 1974. Conodontes de la Formation de Fromelennes du Givétien de l'Ardenne franco-belge. Bulletin de l'Institut royal des Sciences naturelles de Belgique, Sciences de la Terre 50(10), 1-30.

Bultynck, P. 1982. Conodont succession and general faunal distribution across the Givetian-Frasnian boundary in the type area. Papers on the Frasnian-Givetian boundary. Subcommission on Devonian Stratigraphy, Ministery of Economic Affairs, Administration of Mines, Geological Survey of Belgium, 34-59.

Bultynck, P., Casier, J.-G., Coen, M., Coen-Aubert, M., Godefroid, J., Jacobs, L., Loboziak, S., Sartenaer, P. \& Streel, M. 1988. Pre-Congress excursion to the Devonian stratotypes in Belgium. Bulletin de la Société belge de Géologie 96, 249-288.

Bultynck, P., Coen-Aubert, M., Dejonghe, L., Godefroid, J., Hance, L., Lacroix, D., Préat, A., Stainier, P., Steemans, P., Streel, M. \& Tourneur, F. 1991. Les formations du Dévonien Moyen de la Belgique. Mémoires pour servir à l'explication des cartes géologiques et minières de la Belgique $30,1-105$.

CASIER, J.-G. 1977. Contribution à la connaissance des ostracodes du Frasnien de la Belgique. Professional Paper Administration des Mines, Service Géologique de Belgique 147, 1-22.

CASIER, J.-G. 1979. La Zone à Svantovites lethiersi n. sp., zone nouvelle d'Ostracodes de la fin du Frasnien et du début du Famennien. Bulletin de l'Institut royal des Sciences naturelles de Belgique, Sciences de la Terre 51(15), 1-7.

CAsier, J.-G. 1985. Les Ostracodes de la partie supérieure de la Formation de Teferguenite (Givétien) et de la Formation de Marhouna (Givétien-Famennien) de la coupe du Km 30 (Saoura, Sahara algérien). Géobios 18(6), 833-846. DOI 10.1016/S0016-6995(85)80038-3
Casier, J.-G. 1986. Ponderodictya belliloci nov. sp., nouvelle espèce d'ostracode (Metacopida) dans le Frasnien des Bassins de Namur et de Dinant (Belgique et nord de la France). Bulletin de la Société belge de Géologie 95(4), 301-309.

CASIER, J.-G. 1987a. Etude biostratigraphique et paléoécologique des ostracodes du sommet du Givétien et de la base du Frasnien à Ave-et-Auffe (Bord sud du Bassin de Dinant, Belgique). Bulletin de la Société belge de Géologie 96(1), 23-34.

CASIER, J.-G. 1987b. Etude biostratigraphique et paléoécologique des ostracodes du récif de marbre rouge du Hautmont, à Vodelée (partie supérieure du Frasnien, Bassin de Dinant, Belgique). Revue de Micropaléontologie 6(2), 193-204.

CAsier, J.-G. 2004. The mode of life of Devonian entomozoacean ostracods and the Myodocopid Mega-Assemblage proxy for hypoxic events. Bulletin de l'Institut royal des Sciences naturelles de Belgique, Sciences de la Terre 74 (supplement), 73-80.

Casier, J.-G. 2008. Guide de l'excursion: Les ostracodes du Dévonien Moyen et Supérieur du Synclinorium de Dinant, 25-79. In CASIER, J.-G. (ed.) Résumé des communications et guide de l'excursion 22ème Réunion des Ostracodologistes de langue française, Bruxelles 2-4 juin. Institut royal des Sciences naturelles de Belgique.

Casier, J.-G., El Hassani, A. \& Préat, A. 2010. Ostracodes du Dévonien moyen et supérieur du Tafilalt (Maroc). Revue de Micropaléontologie 53, 29-51.

DOI 10.1016/j.revmic.2008.06.003

CAsier, J.-G., Lehmami, M. \& PrÉAt, A. 1997. Ostracodes et sédimentologie du Givétien à Ain Khira (Meseta nord-occidentale du Maroc). Revue de Paléobiologie 16(1), 151-167.

Casier, J.-G., Mamet, B., Préat, A. \& Sanberg, G. 2004. Sedimentology, conodonts and ostracods of the Devonian-Carboniferous strata of the Anseremme railway bridge section, Dinant Basin, Belgium. Bulletin de l'Institut royal des Sciences naturelles de Belgique, Sciences de la Terre 74, 45-68.

Casier, J.-G. \& Olempska, E. 2008. Middle Devonian ostracods from the Frasnes railway section (Dinant Synclinorium, Belgium); taxonomy, biostratigraphy, paleoecology. Bulletin de l'Institut royal des Sciences naturelles de Belgique, Sciences de la Terre 78, 51-66.

CAsier, J.-G. \& PrÉAt, A. 2003. Ostracods and lithofacies of the Devonian-Carboniferous boundary beds in the Avesnois, North of France. Bulletin de l'Institut royal des Sciences naturelles de Belgique, Sciences de la Terre 73, 83-107.

CAsIer, J.-G. \& PRÉAT, A. 2007. Ostracods and lithofacies of the Middle/Upper Devonian boundary stratotype (Puech de la Suque, Montagne Noire, France). Bulletin de la Société géologique de France 4, 293-304. DOI 10.2113/gssgfbull.178.4.293

CAsier, J.-G. \& PréAt, A. 2009. Late Givetian to Middle Frasnian ostracods from Nismes (Dinant Synclinorium, Belgium) and their lithological context. Bulletin de l'Institut royal des Sciences naturelles de Belgique, Sciences de la Terre 79, 87-115.

CAsier, J.-G. \& PrÉat, A. 2010. Comments on Devonian GSSPs and the Devonian/Carboniferous boundary, 52-55. Abstracts $4^{\text {th }}$ French Congress on Stratigraphy "Strati 2010", Paris (France), August 30 - September 2.

Coen, M. 1985. Ostracodes givétiens de l'Ardenne. Mémoires de l'Institut géologique de l'Université de Louvain 32, 1-48.

Coryell, H. \& Malkin, D. 1936. Some Hamilton ostracodes from Arkona, Ontario. American Museum Novitates 891, 1-20.

Egorov, V. 1950. Ostrakody Franskogo Yarusa Russkoy Plat- 
formy - Chast 1: Kloedenellidae. Trudy Vsesoyuznogo neftyanogo nauchno-issledovatelskogo geologo-razvedochnogo instituta (VNIGRI), $175 \mathrm{pp}$.

EINSELE, G. \& RickEN, W. 1991. Introductory remarks, 611-616. In Einsele, G., Ricken, W. \& Seilacher, A. (eds) Cycles and events in stratigraphy. Springer Verlag, Berlin.

FLÜGEL, E. 2004. Microfacies of carbonate rocks. Analysis, interpretation and application. 976 pp. Springer Verlag, Berlin \& New York

Gross, H. 1969. Mitteldevonische Ostracoden zwischen Ruhr und Sieg (Rechtsrheinisches Schiefergebirge). Göttinger Arbeiten zur Geologie und Paläontologie 1, 1-110.

Groos-UfFenorde, H. \& WANG, S.-Q. 1989. The entomozoacean succession of South China and Germany (Ostracoda, Devonian). Courier Forschunginstitut Senckenberg 110, 61-79.

GRÜNDEL, J. 1962. Zur Taxionomie der Ostracoden der Gattendorfia-Stufe Thueringens. Freiberger Forschungshefte, Reihe C (Palaeontologie) 151, 51-105.

HaRdie, L.A. \& GinsburG, R.N. 1977. Layering: the origin and environmental significance of lamination and thin bedding, 50-123. In Hardie, L.A. (ed.) Sedimentation on the modern carbonate tidal flats of Northwest Andros, Bahamas. The John Hopkins University Studies in Geology 22.

Harlton, B. 1933. Micropaleontology of the Pennsylvanian Johns Valley Shale of the Ouachita Mountains, Oklahoma, and its relationship to the Mississippian Caney Shale. Journal of Paleontology 7(1), 3-29.

House, M. 1985. Correlation of mid-Palaeozoic ammonoid evolutionary events with global sedimentary perturbations. $\mathrm{Na}$ ture 313(3), 17-22.

Kegel, W. 1932. Zur Kenntnis Palaeozoischer Ostrakoden: 2. Bairdiidae aus dem Mitteldevon des Rheinischen Schiefergebirges. Jahrbuch der Preussischen Geologischen Landesanstalt zu Berlin 52(1931), 245-250.

Joachimski, M., Breisig, S., Buggisch, W., Talent, J., Mawson, R., Gereke, M., Morrow, J., Day, J. \& Weddige, K. 2009. Devonian climate and reef evolution: Insights from oxygen isotopodes in apatite. Earth and Planetary Science Letters 284, 599-609. DOI 10.1016/j.eps1.2009.05.028

Klapper, G., Feist, R. \& House, M. 1987. Decision on the boundary stratotype for the Middle/Upper Devonian series boundary. Episodes 10(2), 97-101.

Knight, J. 1928. Some Pennsylvanian ostracodes from the Henrietta Formation of Eastern Missouri (part 1). Journal of Paleontology 2(3), 229-267.

Krömmelbein, K. 1952. Ostrakoden-Studien im Devon der Eifel - 2: Die Taxonomische Stellung der Gattung Bairdiocypris und ihre Arten im Mittel-Devon. Senckenbegiana 32(5-6), 319-335.

KRÖMmELBEIN, K. 1954. Eine Ostrakoden-fauna aus der RiffEinlagerung im Plattenkalk der Paffrather Mulde (Givetium, Bergisches Land). Senckenbegiana lethaea 36(5-6), 295-310.

Kummerow, E. 1953. Über oberkarbonische und devonische Ostracoden in Deutschland und in der Volksrepublik Polen. Geologie 7, 1-75.

LefÈvRe, J. 1971. Paleoecological observations on Devonian ostracods from the Ougarta hills (Algeria). Bulletin du Centre de Recherche de Pau - SNPA 5 (supplement), 817-841.

LETHIERS, F. 1970. Quelques ostracodes frasniens du Bas-Boulonnais (France). Annales de la Société géologique du Nord 90(2), 69-75.

Lethiers, F. 1974a. Biostratigraphie des ostracodes dans le
Dévonien supérieur du Nord de la France et de la Belgique. Newsletter in Stratigraphy 3(2), 73-79.

LethiERs, F. 1974b. Les ostracodes du Dévonien Supérieur (Nord de la France, Belgique, Ouest du Canada). 489 pp. Unpublished $\mathrm{PhD}$ thesis, Lille University of Science and Technology.

LethiERs, F. 1982. Biostratigraphie et caractères sédimentaires du Frasnian en Boulonnais. Bulletin du BRGM 2(3), 211-217.

Lethiers, F. 1984. Zonation du Dévonien Supérieur par les ostracodes (Ardennes et Boulonnais). Revue de Micropaléontologie 27(1), 30-42.

Lethiers, F. \& Crasquin-Soleau, S. 1988. Comment extraire les microfossiles à tests calcitiques des roches calcaires dures. Revue de Micropaléontologie 31(1), 56-61.

Lethiers, F., Racheboeuf, P., Baudin, F. \& Vaccari, E. 2001. A typical Malvinokaffric Givetian ostracod fauna from Bolivia. Revue de Micropaleontologie 44(4), 301-317. DOI 10.1016/S0035-1598(01)90123-0

Lethiers, F. \& Whatley, R. 1995. Oxygénation des eaux et ostracodes filtreurs: application au Dévonien-Dinantien. Geobios 28(2), 199-207. DOI 10.1016/S0016-6995(95)80227-4

MaGne, F. 1964. Données micropaléontologiques et stratigraphiques dans le Dévonien du Boulonnais (France) et du Bassin de Namur (Belgique). 172 pp. Thèse de 3ème cycle, Université de Paris, Société nationale des Pétroles d'Aquitaine, Centre de Recherches de Pau.

MaILLET, S. 2010. Les ostracodes du Givétien supérieur au bord sud du Synclinorium de Dinant (Formation de Fromelennes, région de Givet, Ardennes): biostratigraphie, paléoécologie, recherche de bioévénements. 39 pp. Unpublished master Environment, Université Lille 1.

MALEC, J. \& RACKI, G. 1992. Givetian and Frasnian ostracod associations from the Holy Cross Mountains. Acta Palaeontologica Polonica 37(2-4), 359-384.

Mamet, B. \& Préat, A. 1985. Sur la présence de Palaeomicrocodium (Algue?, Incertae sedis?) dans le Givétien Inférieur de Belgique. Géobios 18(3), 389-392.

DOI 10.1016/S0016-6995(85)80101-7

Mamet, B. \& PrÉAt, A. 1987. Algues givétiennes du bord sud du Bassin de Dinant et des régions limitrophes. Annales de la Société géologique de Belgique 109, 431-454.

Mamet, B. \& PréAt, A. 2005a. Sédimentologie de la série viséenne d'Avesnes-sur-Helpe (Avesnois, Nord de la France). Geologica Belgica 81(2), 91-107.

Mamet, B. \& PrÉAt, A. 2005b. Microfaciès d'une lentille biohermale à la limite Eifélien-Givétien (Wellin, bord sud du Synclinorium de Dinant). Geologica Belgica 8(3), 85-111.

Marschall, J., Brown, J. \& Astin, T.R. 2011. Recognizing the Taghanic Crisis in the Devonian terrestrial environment and its implications for understanding land-sea interactions. Palaeogeography, Palaeoclimatology, Palaeoecology 304, 165-183. DOI 10.1016/j.palaeo.2010.10.016

Matern, H. 1929. Die Ostracoden des Oberdevon, 1 Teil: Aparchitidae, Primitiidae, Zygobolbidae, Beyrichiidae, Kloedenellidae, Entomidae. Abhandlungen der Preussischen Geologischen Landesanstalt, Neue Folge 118, 1-100.

Matthew, G. 1886. Illustration of the fauna of the St. John Group continued No. 3: Descriptions of new genera and species. Proceedings and transactions of the Royal Society of Canada, Series 1, 3 (1885)(4), 29-84.

McGill, P. 1963. Upper and middle Devonian ostracodes from the Beaverhill Lake Formation, Alberta, Canada. Bulletin of Canadian Petroleum Geology 11(1), 1-26. 
McGill, P. 1966. Ostracods of probable Late Givetian age from Slave Point Formation, Alberta. Bulletin of Canadian Petroleum Geology 14(1), 104-133.

Milhau, B. 1982. Les ostracodes du Givétien supérieur de l'Ardenne et du Boulonnais. 65 pp. Unpublished DEA, Lille University of Science and Technology.

Milhau, B. 1983a. Valeur biostratigraphique et paléoécologique des ostracodes du Givétien Supérieur de la région-type. Geobios 16(3), 347-359. DOI 10.1016/S0016-6995(83)80004-7

Milhau, B. 1983b. Ostracodes du Givétien supérieur du Boulonnais. Corrélations avec l'Ardenne. Annales de la Société géologique du Nord 102, 217-239.

Milhau, B. 1988. Ostracodes du Givétien de Ferques (Dévonien Moyen, Boulonnais - France). Biostratigraphie du Paléozoїque 7, 379-491.

Milhau, B. 1996. Les ostracodes au voisinage de la limite EifélienGivétien au Maroc: comparaison avec ceux d'Europe occidentale. Annales de la Société géologique du Nord 4(2), 71-81.

Narkiewicz, K. \& Bultynck, P. 2010. The upper Givetian (Middle Devonian) subterminus conodont Zone in North America, Europe and North Africa. Journal of Paleontology 84(4), 588-825. DOI 10.1666/10-029.1

NAZiK, A. \& Becker, G. 2008. Devonian ostracodes from the Eastern and Central Taurides (Turkey). Abstracts and Programme Final Meeting of IGCP 497 and IGCP 499, Frankfurt-am-Main, September 30 - October 3, 218.

Nazik, A., Yalçin, N., Wilde, V., Wehrmann, A., Yilmaz, I., Schindler, E., Kozlu, H. \& Bozdogan, N. 2012. Palaeoecology and palaeogeography of ostracods from the Devonian of Halevikdere (Eastern Taurides, Turkey). Turkish Association of Petroleum geologists, Special Publication 6, 35-36.

Olempska, E. 1979. Middle to Upper Devonian Ostracoda from the Southern Holy Cross Mountains, Poland. Palaeontologia Polonica 40, 57-162.

PaeckelmanN, W. 1921. Oberdevon und Untercarbon der Gegend von Barmen. Jahrbuch der Preussischen Geologischen Landesanstalt zu Berlin 41(2), 110-114.

POKORNÝ, V. 1950. Skořepatci střednodevonských "červených vápenců korálových” z Čelechovic. Sborník Státního geologického ústavu Československé republiky, Oddíl paleontologický 17, 513-632.

PoKorný, V. 1958. Ostracoda - Muschelkrebse. Grundzuege der Zoologischen Mikropalaeontologie, 2, 66-322, 305-402.

Polenova, E. 1952. Ostrakody verkhney chasti Zhivetskogo Yarusa Russkoy platformy. Trudy Vsesoyuznogo neftyanogo nauchno-issledovatelskogo geologo-razvedochnogo instituta (VNIGRI), novaya seriya 60(5), 65-156.

Polenova, E. 1953. Ostrakody devonskikh otlozheniy Tsentralnogo devonskogo polya i Srednego Povolzhya. Trudy Vsesoyuznogo neftyanogo nauchno-issledovatelskogo geologorazvedochnogo instituta (VNIGRI), novaya seriya 68, 1-157.

Polenova, E. 1955. Ostrakody devona Volgo-Uralskoy oblasti. Trudy Vsesoyuznogo neftyanogo nauchno-issledovatelskogo geologo-razvedochnogo instituta (VNIGRI), novaya seriya 87, 191-287.

Polenova, E. 1960. Devonskie ostrakody Kuznetskogo basseyna i Minusinskoy kotloviny. Trudy Vsesoyuznogo neftyanogo nauchno-issledovatelskogo geologo-razvedochnogo instituta (VNIGRI), novaya seriya 152, 1-139.

PRÉAT, A. 1984. Etude lithostratigraphique et sédimentologique du Givétien belge (Bassin de Dinant). 466 pp. Unpublished $\mathrm{PhD}$ thesis, University of Brussels, Belgium.
Préat, A., Capette, L., Blockmans, S., Dumoulin, V. \& Mamet, B. 2007. Microfaciès d'une lentille biohermale à la limite Eifélien-Givétien ("Fondry des Chiens", Nismes, bord sud du Synclinorium de Dinant). Geologica Belgica 10(1-2), 3-25.

Préat, A. \& Kasimi, B. 1995. Sédimentation de rampe mixte silico-carbonatée des couches de transition eiféliennesgivétiennes franco-belges. Première partie: microfaciès et modèle sédimentaire. Bulletin des Centres de Recherches Exploration-Production Elf Aquitaine 19(2), 329-375.

PréAt, A. \& Mamet, B. 1989. Sédimentation de la plate-forme carbonatée givétienne franco-belge. Bulletin des Centres de Recherches Exploration-Production Elf Aquitaine 13(1), 47-86.

Rabien, A. 1954. Zur Taxionomie und Chronologie der Oberdevonischen Ostracoden. Abhandlungen des Hessischen Landesamtes für Bodenforschung 9, 1-268.

Racheboeuf, P., Casier, J.-G., Plusquellec, Y., Toro, M., Mendosa, D., Da Gloria Pires de Carvalho, Le Herissé, A., Paris, F., Fernadez-Martinez, E., Tourneur, F., Broutin, J., Crasquin, S. \& Janvier, P. 2012. New data on the Silurian-Devonian paleontology and biostratigraphy of Bolivia. Bulletin of Geosciences 87(2), 269-314.

DOI 10.3140/bull.geosci.1248

RACKI, G. 1993. Evolution of the bank to reef complex in the Devonian of the Holy Cross Mountains. Acta Palaeontologica Polonica 37, 87-182.

RozhdestVEnskaya, A. 1962. Srednedevonskie ostrakody zapadnogo sklona yuzhnogo Urala, Preduralskogo progiba i platformennoy chasti Bashkirii, 169-349. In ThYAZEVA, A., Rozhdestvenskaya, A. \& Chibrikova, E. (eds) Brakhiopody, ostrakody i spory srednego i verkhnego devona Bashkirii. 477 pp. Izdatelstvo Akademii nauk SSSR, Moscow.

RozhDESTVENSKAYA, A. 1972. Ostrakody verkhnego devona Bashkirii. 192 pp. Nauka, Moscow.

SARS, G. 1888. Nye bidrag til kundskaben om middelhavets Invertebratfauna: 4. Ostracoda Mediterranea (Sydeuropaeiske Ostracoder). Archiv for Mathematik og Naturvidenskab 12(1887), 173-324.

Scotт, H. 1959. Type species of Paraparchites Ulrich \& Bassler. Journal of Paleontology 33(4), 670-674.

Shaver, R. 1961. Family Bairdiocyprididae Shaver n. fam., 364-367. In Moore, R. (ed.) Treatise on Invertebrate Paleontology. Part Q, Arthropoda 3, Crustacea, Ostracoda. Geological Society of America \& University of Kansas Press, Boulder \& Lawrence.

Swartz, F. 1936. Revision of the Primitiidae and Beyrichiidae, with new ostracoda from the Lower Devonian of Pennsylvania. Journal of Paleontology 10(7), 541-586.

Tebutt, G.E., Conley, C.D. \& Boyd, D.W. 1965. Lithogenesis of a distinctive carbonate rock fabric, 1-13. In PARKER, R.B. (ed.) Contribution to Geology 4. University of Wyoming, Laramie.

TuCKer, M. \& GARLAND, J. 2010. High-frequency cycles and their sequence stratigraphic context: orbital forcing and tectonic controls on Devonian cyclicity in Belgium. Geologica Belgica 13(3), 213-240.

UlRICH, E. 1894. The lower Siliurian Ostracoda of Minnesota. Report of the Geological and Natural History Survey of Minnesota 3(2), 629-693.

Ulrich, E. \& Bassler, R. 1908. New American Paleozoic ostracoda. Preliminary revision of the Beyrichiidae, with descriptions of new genera. Proceedings of the United States $\mathrm{Na}$ tional Museum 35(1646), 277-440.

DOI 10.5479/si.00963801.35-1646.277 
Wesphal, H., Riegel, B. \& Eberli, G.P. 2010. Carbonate depositional systems: assessing dimensions and controlling parameters. The Bahamas, Belize and the Persian/Rabina Gulf. 235 pp. Springer Verlag, Dordrecht \& New York.

Zaspelova, V. 1952. Ostrakody semeystva Drepanellidae iz otlozheniy verkhnego devona Russkoy platformy. Trudy Vse- soyuznogo neftyanogo nauchno-issledovatelskogo geologorazvedochnogo instituta (VNIGRI), novaya seriya 60(5), 157-216.

ZвiKowsKA, B. 1983. Middle to Upper Devonian ostracods from northwestern Poland and their stratigraphic significance. Palaeontologica Polonica 44, 1-108.

\section{Annex 1: Systematic position of ostracod species identified in the Fromelennes Formation at Sourd d'Ave}

Order Palaeocopida

Suborder Palaeocopina

Superfamily Kirkbyoidea

Family Amphissitidae Knight, 1928

Amphissites sp. indet. Figure 8A

Superfamily Beyrichioidea

Family Beyrichiidae Matthew, 1886

Kozlowskiella plana (Kummerow, 1953). Figure 8B

Aparchitellina irgizlensis Rozhdestvenskaya, 1962. Figure 8C

Aparchitellina aff. glabra Rozhdestvenskaya, 1962. Figure 8D

Kozlowskiella sp. indet. Figure 8E

Superfamily Nodelloidea

Family Nodellidae Zaspelova, 1952

Nodella faceta Rozhdestvenskaya, 1972. Figure 8F

Superfamily Aparchitoidea

Family Rozhdestvenskayitidae Mc Gill, 1966

Fellerites sp. indet. Figure 8G.

Superfamily Primitiopsoidea

Family Pribylitidae Pokorný, 1958

Parapribylites cf. cingulatus (Kummerow, 1953). Figure 8H

Kielciella fastigans (Becker, 1964). Figure 8I

Gravia? sp. indet. Figure 8J

Family Primitiopsidae Swartz, 1936

Coryellina? sp. indet. Figure $8 \mathrm{~K}$

?Family Buregiidae Polenova, 1953

Buregia ovata (Kummerow, 1953). Figure 8L

Superfamily Youngiellacea

Youngiella sp. indet. Figure 8M.

Suborder Paraparchitocopina

Superfamily Paraparchitoidea

Family Paraparchitidae Scott, 1959

Coeloenellina optata (Polenova, 1955). Figure 8N

Coeloenellina sp. indet. Figure 80

Suborder Platycopina

Superfamily Cytherelloidea

Family Cavellinidae Egorov, 1950

Cavellina sp. A, aff. clara Polenova, 1955. Figure 9A

Cavellina rhenana Krömmelbein, 1954. Figure 9B

Cavellina macella Kummerow, 1953. Figure 9C

Superfamily Kloedenelloidea

Family Kloedenellidae Ulrich \& Bassler, 1908

Poloniella sp. indet.

Uchtovia abundans (Pokorný, 1950). Figure 9D

Uchtovia refrathensis (Krömmelbein, 1954). Figure 9E

Uchtovia cf. kloedenellides (Adamczak, 1968). Figure 9F
Evlanella germanica Becker, 1964. Figure 9G

Evlanella cf. mitis Adamczak, 1968. Figure 9H

Family Knoxitidae Egorov, 1950

Knoxiella? sp. A. Figure 9I

Order Podocopida

Suborder Metacopina

Superfamily Healdioidea

Family Healdiidae Harlton, 1933

Cytherellina obliqua (Kummerow, 1953). Figure 9J

Cytherellina sp. II in Groos (1969)? Figure 9K

Cytherellina sp. A, aff. perlonga (Kummerow, 1953). Figure 9L

Superfamily Thlipsuroidea

Family Thlipsuridae Ulrich, 1894

Polyzygia neodevonica (Matern, 1929). Figure 9M

Family Ropolonellidae Coryell \& Malkin, 1936

Euglyphella europaea Coen, 1985. Figure 9N

Family Quasillitidae Coryell \& Malkin, 1936

Quasillitidae gen. and sp. indet.

Suborder Podocopina

Superfamily Bairdioidea

Family Acratiidae Gründel, 1962

Acratia lucea Maillet nom. nud. Figure 90

Acratia sp. A, aff. sp. G II in Magne (1964). Figure 10A

Family Bairdiidae Sars, 1888

Bairdia cf. siliklensis Rozhdestvenskaya, 1962. Figure 10B.

Bairdia paffrathensis Kummerow, 1953. Figure 10C

Bairdiacypris antiqua (Pokorný, 1950). Figure 10D

Bairdiacypris sp. indet.

"Schneideria" groosae (Becker, 1971). Figure 10E

Superfamily Bairdiocypridoidea

Family Pachydomellidae Berdan \& Sohn, 1961

Tubulibairdia? sp. A. Figure 10F

Microcheilinella cf. affinis Polenova, $1955=$ Microcheilinella sp.

sensu Coen, 1985. Figure 10G

Family Bairdiocyprididae Shaver, 1961

Bairdiocypris cf. breuxensis Casier \& Olempska, 2008. Figure 10H

Bairdiocypris corniger Rozhdestvenskaya, 1962?

Bairdiocypris sp. indet.

Orthocypris kummerowi Zbikowska, 1983? Figure 10I

Orthocypris? bicarinata Maillet nom. nud. Figure 10J

Order Eridostraca

Family Cryptophyllidae Adamczak, 1961

Cryptophyllus sp. 3 in Magne (1964). Figure 10K

Cryptophyllus sp., aff. materni Becker, 1971. Figure 10L 